\title{
Information Asymmetry, Market Segmentation and the Pricing of Cross-listed Shares: Theory and Evidence from Chinese A and B Shares
}

\author{
Sugato Chakravarty \\ Purdue University \\ West Lafayette, IN 47906
}

\author{
Asani Sarkar ${ }^{1}$ \\ Federal Reserve Bank of New York \\ New York, NY 10045 \\ Lifan $\mathrm{Wu}$ \\ Department of Finance and Law \\ California State University, Los Angeles \\ Los Angeles, CA 90032
}

Previous version: January 1998

This version: July 1998

\begin{abstract}
JEL Classification numbers G12, G14, G15

In contrast to most other countries, Chinese foreign class $B$ shares trade at an average discount of about 60 percent to the prices at which domestic $A$ shares trade. We argue that one reason for the large price discount of $B$ shares is because foreign investors have less information on Chinese stocks than domestic investors. We develop a model, incorporating both informational asymmetry and market segmentation, and derive a relative pricing equation for $A$ shares and $B$ shares. We show theoretically that an $A$ share index security, tradable by foreigners, increases the liquidity of $B$ shares. Our empirical study of Chinese stocks supports the predictions of our model. Specifically, we show that our model-based proxies for informational asymmetry explain a significant portion of the cross-sectional variation of the $B$ share discounts.
\end{abstract}

1 Research Department, 33 Liberty Street, New York, NY 10045. Telephone 212-720-8493, fax 212-7201582, e -mail ASANI.SARKAR@NY.FRB.ORG. We gratefully acknowledge the comments of an anonymous referee, Stephen Brown, Jean Helwege and Jay Ritter. All mistakes are ours alone. The views here are those of the authors and do not necessarily reflect the views of the Federal Reserve Bank of New York or the Federal Reserve System 


\section{INTRODUCTION}

The finance literature has, in recent years, documented many cases where foreign class shares (i.e., shares offered to foreign investors) trade at a premium relative to domestic shares (Hietala, 1989; Bergstrom, Rydqvist and Sellin, 1993; Bailey and Jagtiani, 1994; Stulz and Wasserfallen, 1995). ${ }^{2}$ However, the reverse case---where foreign shares trade at a price discount relative to domestic shares---has received less attention. An example is the Chinese stock market, where domestic investors can only trade $A$ (local) shares, while foreign investors are restricted to trading $B$ (foreign) shares. ${ }^{3}$ Although the two share classes are identical with respect to shareholder rights, such as voting and profit sharing rights, foreign investors pay only a small fraction of the prices that local investors pay for identical stocks (Bailey, 1994; Wo, 1997; Chen and Su, 1998).

In this paper, we examine, both theoretically and empirically, the pricing of dual listed Chinese stocks. Consistent with the previous literature, we find that $B$ shares trade at a substantial discount relative to $A$ shares. Specifically, the daily mean and median price discounts for the $B$ shares in our sample, for the period January 1994 to December 1996, are 58.68 percent and 60.71 percent, respectively. We argue that the discount exists because foreign investors have less information about local firms, relative to domestic investors. We develop a theoretical model, incorporating both asymmetric information and market segmentation, and

\footnotetext{
${ }^{2}$ For example, Hietala (1989) investigates the price premia for Finnish stock market for the period 1984-1985 and reports a monthly mean premium of $30 \%$ for the foreign share price. Bergstrom, Rydqvist and Sellin (1993) show price premia of foreign shares ranging from 5\% to 68\% for 196 firms listed on the Stockholm Stock Exchange during the period 1980-1987. Bailey and Jagtiani (1994) document an average premium of $19 \%$ on the Alien Board of the Stock Exchange of Thailand. Stulz and Wasserfallen (1995) find foreign investors pay higher prices for shares than domestic investors for a sample of 19 firms listed in Switzerland.
} 
derive a relative pricing formula for $A$ and $B$ shares. In the theoretical model, we also explore the effect of introducing index securities on the liquidity of the $B$ share market. In our empirical tests, we construct a proxy for informational asymmetry, and provide evidence in support of our theoretical predictions.

Why do foreign shares trade at such large discounts in China, and at a premium in other markets? Many of the usual explanations for price differences between domestic and foreign shares do not appear to be important for China. Foreign investors face low barriers to trading $B$ shares, relative to domestic investors trading $A$ shares. There is no time lag in trading between the domestic and the foreign shares; and neither dividends nor capital gains are taxed in China. Incomplete diversification on the part of domestic investors and foreign ownership restrictions are more likely to lead to price premia rather than discount for the $B$ shares. ${ }^{4}$

We argue that foreign investors find it more difficult to acquire and assess information about local Chinese firms, relative to domestic investors. These difficulties are due to language barriers, different accounting standards, and lack of reliable information about the local economy and firms (Kaye and Cheng, 1992; Sze, 1993). Many listed $B$ share firms do not fully and promptly disclose all material changes in their business conditions, and published statements are not always prepared according to international accounting standards. While these problems face

\footnotetext{
${ }^{3}$ As Wo (1997) points out, the Chinese equity markets are the only equity markets covered by the International Finance Corporation that completely restrict cross-class trading.

${ }^{4}$ Eun and Janakiramanan (1986) and Alexander, Eun and Janakiramanan (1987) develop a model of international asset pricing in the presence of the foreign ownership restrictions on the domestic shares. They show that foreign investors offer a premium to domestic investors when the ownership constraint is binding. Hietala (1989) points out that domestic investors cannot diversify away the specific country risk as effectively as foreign investors can.
} 
all investors, they are worse for foreign investors since local investors may be able to tap informal local information sources that are unavailable to nonresident investors. ${ }^{5}$

While information asymmetries may be present in other countries, they are particularly relevant for China. For one thing, unlike countries such as Finland, Sweden and Switzerland, where foreign shares trade at a premium, China is an emerging stock market. In fact, China had no stock markets till 1990 , and $B$ shares were not traded till 1992 . In common with other emerging markets, Chinese stock exchanges lack certain features that could otherwise mitigate information asymmetry for foreigners. For example, real-time market information and $B$ share prices are not available and Chinese managers do not recognize the importance of disclosure (Sze, 1993). Further, share manipulation and insider trading are considered to be rampant and investor protections rights are not legally codified (Kaye and Cheng, 1992). While the severity of these problems may have declined over time, they continue to be relevant.

As indirect evidence in favor of the information asymmetry hypothesis, we note that, in our sample, the mean daily price discount for the $B$ shares listed on the Shanghai exchange is 65.62 percent, compared to 48.71 percent for $B$ shares trading on Shenzhen. One interpretation for this difference is that there is less information available about Shanghai-listed firms. The Shanghai exchange is dominated by former State-owned enterprises, whereas the Shenzhen market features more joint venture companies, many involving Hong Kong Chinese investors. As Sze (1993) points out, the former State-owned enterprises are most likely to suffer from poor accounting and disclosure standards, whereas many joint venture companies are managed by the Hong Kong partners.

\footnotetext{
${ }^{5}$ For a description of informal sources of information for local investors, see "Stock Market Mania is Sweeping China; Speculators Abound," in the Wall Sreet Journal, page A1, August 27, 1997.
} 
We derive a simple asset pricing model, based on Grossman and Stiglitz (1980), that incorporates both asymmetric information and market segmentation in a noisy rational expectations framework. Domestic investors trade $A$ shares only, and have private information about the future returns of the domestic stock. Foreign investors trade $B$ shares and foreign stocks, but do not have any special information about the domestic stock. However, foreign investors observe the current price of $A$ shares, which is informative of both $A$ and $B$ share returns. Hence, the $A$ and $B$ share markets are linked in information, although they are segmented in trading.

Based on our model, we derive a relationship between the prices of $A$ and $B$ shares that depends on both the degree of asymmetric information and foreign investors' diversification benefits (since the $B$ share market expands foreign investors' opportunity sets). When there is no asymmetric information, our model predicts a premium for foreign $B$ shares, as in previous models of market segmentation. With severe asymmetric information, however, $B$ shares may trade at a discount relative to $A$ shares. The degree of information asymmetry is negatively related to the covariance of the returns between $B$ and $A$ shares, and positively related to the variance of $B$ share returns.

We extend the model to allow for the possibility of an index security based on the $B$ shares. ${ }^{6}$ Sze (1993) reports that foreign investors recommend such a $B$ share index to enhance the liquidity of the $B$ share market. Subrahmanyam (1991), and Gorton and Pennacchi (1993) show that uninformed traders can reduce their losses to informed traders by trading an index security, or a basket of securities. We show, however, that the introduction of a $B$ share index does not affect investors' demand for shares, nor the prices of $A$ and $B$ shares. The reason is 
that, since $A$ and $B$ share markets are segmented in trading, the $B$ share index does not change the degree of informational asymmetry between domestic and foreign investors. As an alternative, we propose an index security of $A$ shares that can be traded by foreign investors (although the individual $A$ shares are still restricted to domestic investors). We show that introduction of the $A$ share index increases trading volume and decreases the price discount in the $B$ share market.

In our empirical study, we use a sample of 39 dually listed firms on the Shanghai and Shenzhen stock exchanges to test the relationship between information asymmetry and the price discount on the $B$ shares. We use the coverage of Chinese companies in the English press as an (inverse) measure of information asymmetry, since firms with wider coverage in the media may be easier to monitor. We find preliminary evidence consistent with the asymmetric information hypothesis: the magnitude of the $B$ share price discount is negatively related to the number of news reports in both the Shanghai and Shenzhen stock markets; and, second, there are more stocks for which the $A$ share returns lead the $B$ share returns, than the other way around.

Next, we specify a cross-sectional regression, based on our theoretical model, to explain the determinants of the $B$ share price discounts. We relate the discount to the covariance between $A$ share and $B$ share returns, the variance of $B$ share returns, and the media coverage variable---all proxies for informational asymmetry. We include the covariance between $B$ share returns and the S\&P 500 index to measure the diversification effect. We also control for the relative supplies of the $A$ and $B$ shares and the size (i.e., market capitalization) of the stock. The results are consistent with our theory. The media coverage and the $B$ share return variance variables are highly significant, but the diversification variable is not. In addition, firm size and

\footnotetext{
${ }^{6}$ We thank the referee for suggesting this extension to us.
} 
the relative supply of $A$ and $B$ shares are also significant. When we include an exchange dummy, our specification explains 67 per cent of the cross-sectional variance of the $B$ share discounts.

Other papers have also studied the Chinese $A$ and $B$ share markets. Bailey (1994) finds preliminary evidence for foreign share discounts. Wo (1997) conducts a bivariate Granger causality test of $A$ and $B$ share returns and finds evidence of two way information flows between the markets for his sample period (January 1993 to October 1995). Chen and Su (1998) find that the $A$ and $B$ share markets are not perfectly integrated. They use the returns on the Chinese stock index as a proxy for informational asymmetry and find that it is positively related to the difference in $A$ share and $B$ share returns. However, the Chinese stock index return is more reasonably interpreted as a proxy for local market risk, instead of informational asymmetry. Further, since local investors are more exposed to local market risk, $A$ share returns are more sensitive to the local index than $B$ share returns. Unlike the current paper, none of the above papers test for informational asymmetry based on a theoretical model, nor do they construct direct empirical proxies for informational asymmetry (such as our media coverage variable).

In related literature, Errunza and Losq (1985) show that securities inaccessible to a subset of investors require greater risk premia. Merton (1987) models a limiting case where investors only invest in a subset of available securities with which they are familiar, because of high costs of gathering and processing data. In a recent paper, Stulz and Wasserfallen (1995) demonstrate that the deadweight costs (including information costs) for holding risky assets differ across investors and across countries, causing demand functions for domestic shares to differ between domestic and foreign investors. Brennan and Cao (1997) argue that while the 
case for information asymmetry is weak for institutional investors, there is little doubt that such asymmetry exists for average (individual) investor in different countries.

The rest of the paper is organized as follows. Section II provides background information about $A$ and $B$ shares. Section III derives pricing models for both $A$ shares and $B$ shares. Section IV presents empirical evidence on the performances of $A$ and $B$ shares and tests the model. Section V presents conclusions.

\section{STRUCTURE OF THE $A$ AND $B$ SHARE MARKETS}

China's two securities markets, the Shanghai Securities Exchange (SSE) and the Shenzhen Stock Exchange (SZE), were established in November 1990 and July 1991, respectively. The shares initially listed on the SSE and SZE were called "A shares" and could only be traded by Chinese citizens. Starting in early 1992, another category of shares, known as " $B$ shares", was introduced exclusively for foreign investors. By the end of 1996, 514 companies had gone public, of which 287 firms were listed on the SSE and the remaining 227 firms were listed on the SZE. Of the 85 firms that have issued B shares, 42 are traded on the SSE and 43 are traded on the SZE.

The class $A$ shares are domestic ordinary shares denominated and traded in Renminbi (i.e., the Chinese currency) by Chinese citizens. The majority of $A$ shares are issued by Stateowned enterprises and can be classified into three categories by type of ownership. (1) State shares, which are shares held by the government through a designated government agency; (2) Legal shares, which are shares held by the Chinese "legal persons" (i.e., the enterprises and/or other economic entities but not individuals); and (3) Public shares, which are shares owned by 
ordinary Chinese citizens. According to the Chinese securities rules, only public shares can be traded on the exchanges. Therefore these public shares are also called "tradable" shares. The State and Legal shares are issued at the time the company is formed, but cannot be traded. These special regulations ensure that the government maintains control over the listed companies. $^{7}$

The class $B$ shares are special Renminbi-denominated ordinary shares offered to foreign investors, but they are traded in foreign currency. Owners of $B$ shares have the same rights and bear the same obligations as holders of $A$ shares. $B$ shares are traded for, and their dividends paid in, foreign currency: US dollars for the Shanghai $B$ shares and Hong Kong dollars for the Shenzhen $B$ shares. Individual investors are allowed to hold a maximum of 25 percent of a firm's $B$ shares, but total foreign ownership (through the $B$ share issues) cannot exceed 49 percent of a firm's total shares. The trading mechanism for $\mathrm{B}$ shares is similar to that for the $A$ shares. $A$ share orders are placed through local brokers, and $B$ share orders are sent to either local or foreign brokers. All orders are executed through a computerized batch system. Table 1 describes the segmented stock markets in China.

\section{A MODEL OF PRICING CROSS-LISTED $A$ AND $B$ SHARES UNDER ASYMMETRIC INFORMATION AND MARKET SEGMENTATION}

In this section, we develop a simple pricing model of $A$ and $B$ shares, assuming the two markets are segmented. The model is based on Grossman and Stiglitz (1980), who introduce informational asymmetries into a noisy rational expectation model of asset pricing. We modify

\footnotetext{
${ }^{7}$ There is a debate recently as to whether the State and Legal shares should be allowed into the market. However, this relaxation is not likely to happen in the near future.
} 
the model to allow for market segmentation. The intuition behind the model is explained most simply when there is one domestic $A$ share stock and one foreign $B$ share stock. Later, we allow multiple stocks and the possibility of trading in index securities.

There are two types of assets: a safe asset with return $r_{f}$ and two risky assets---domestic and foreign. Two classes of shares are written on the domestic asset. Class $A$ shares are held exclusively by domestic investors, whereas class $B$ shares are held exclusively by foreign investors. In addition, foreign investors hold a purely foreign stock $C$, which cannot be traded by domestic investors. The current market prices of these stocks $p_{i}, i=a, b, c$, are known to all investors. But, future prices are not known, and hence $u_{i}$, the end-of-period return of stock $i$, $i=a, b, c$ (corresponding to the $A, B$ and $C$ class shares, respectively) is not known to the investors.

Following Stulz and Wasserfallen (1995), we assume that domestic investors have advantages in gathering and processing information about the domestic asset, relative to foreign investors. Since both $A$ and $B$ shares are written on the same domestic asset, we formally represent the future return process of the $A$ and $B$ shares as follows:

$$
\begin{aligned}
& \tilde{u}_{a}=\phi+\varepsilon \\
& \tilde{u}_{b}=\phi+\gamma
\end{aligned}
$$

where $\phi$ is the true return of the asset and $\varepsilon, \gamma$ are error terms. We assume that domestic investors observe $\phi$ while foreigner investors can only observe the prices $p_{a}, p_{b}$ and $p_{c}$.

Below, we specify some properties of the random variables. $\phi, \varepsilon$ and $\gamma$ have a trivariate normal distribution with variances $\operatorname{Var}(\phi), \operatorname{Var}(\varepsilon)$, and $\operatorname{Var}(\gamma)$, respectively. Also: 


$$
\begin{aligned}
& \mathrm{E}(\varepsilon)=\mathrm{E}(\gamma)=0 \\
& \mathrm{E}(\varepsilon \phi)=\mathrm{E}(\gamma \phi)=0 \\
& \mathrm{E}\left(\tilde{u}_{i} \mid \phi\right)=\phi, \operatorname{Var}\left(\tilde{u}_{a} \mid \phi\right)=\sigma_{\varepsilon}^{2}, \operatorname{Var}\left(\tilde{u}_{b} \mid \phi\right)=\operatorname{Var}(\gamma)
\end{aligned}
$$

Given the information structure, and the segmentation between $A$ and $B$ share markets, domestic investors' demands depend on $\phi$ and $p_{a}$. Foreign investors' demands depend only on the stock prices $p_{i}, i=a, b, c$. However, we assume that foreign investors have rational expectations; over time, they learn the relationship between the distribution of $u_{a}$ and the price $p_{a}$ and use this to acquire additional knowledge about the distribution of $u_{b}$ (since $\phi$ and $u_{b}$ are linked by (2)). This knowledge is then used to derive the demand for $B$ shares.

Let $x_{i}, i=a, b, c$, represent the supply of shares in markets $A, B$, and $C$, respectively. We assume that $x_{i}, i=a, b, c$, is normally distributed with mean $\mathrm{E}\left(x_{i}\right)$, variance $\operatorname{Var}\left(x_{i}\right)$ and is independent of all other random variables in the model. Consistent with Grossman and Stiglitz (1980), we further assume that investors know the supply in their own market, but not in markets where they are not trading. In particular, domestic investors know $x_{a}$ but foreign investors do not. Therefore, foreign investors cannot infer $\phi$ perfectly from observing the $A$ share price, since they cannot distinguish between variations in price due to changes in $\phi$, and variations in price due to changes in $x_{a}$.

We denote price functions $P_{i}, i=a, b, c$, to distinguish them from price realizations $p_{i}$, $i=a, b$, and $c$. In equilibrium, the price functions are determined so that the demand for shares in each market equals the supply. For example, the domestic price function $P_{a}\left(x_{a}, \phi\right)$ will, in equilibrium, be such that the supply of $A$ shares $x_{a}$ equals $n_{a}$, the domestic investors' demand for 
$A$ shares. Note that, since foreign investors do not know $x_{a}$ or $\phi$, they view $P_{a}\left(x_{a}, \phi\right)$ as a random variable $\widetilde{P}_{a}\left(x_{a}, \phi\right)$.

Summarizing, the information set of domestic investors is $I_{a}=\left\{\phi, p_{a}, p_{b}, p_{c}\right\}$, whereas the information set of foreign investors is $I_{b}=\left\{p_{a}, p_{b}, p_{c} ; P_{a}{ }^{*}\right\}$, where $P_{a}{ }^{*}(.,$.$) is some particular$ price function of $\left(x_{a}, \phi\right)$ determined in the $A$ share market (see below for further details).

We assume the usual regularities: there are no transaction costs; all assets are infinitely divisible; and trading is competitive in the $A$ share and $B$ share markets. We also assume that domestic and foreign investors have the same degree of risk aversion and the same risk-free return $r_{f}$ and that their utility functions are exponential, i.e.,

$$
u\left(\tilde{w}_{1 i}\right)=-e^{-R \tilde{w}_{1 i}}
$$

where $R$ is the coefficient of constant absolute risk-aversion and $w_{l i}$ is the end-of-period wealth

of investor $i, i=a$ (domestic), $b$ (foreign). Since $w_{l i}$ is normally distributed, this implies that investors trade solely on the basis of the expected value and variance of their wealth, conditional on their information set $I_{i}, i=a, b$.

\section{A. The Relative Pricing Model With No Index Security}

In this section, we assume that there is just one stock traded in each market. Hence, there are no index securities. An investor of type $i, i=a, b$, chooses the number of shares of the risk-free asset $M_{i}$ and the number of shares of the risky asset $n_{i}$ to maximize the expected utility of his end-of-period wealth, conditional on his information set $I_{i}$ and subject to his budget constraint. We normalize so that the price of the risk-free asset is one. 
Let an investor of type $i$ have initial endowment assets $w_{0 i}$. Thus, a domestic investor chooses $n_{a}, M_{a}$ to maximize

$$
\mathrm{E}\left[\left\{u\left(\widetilde{w}_{1 a}\right)\right\} \mid I_{a}\right]
$$

subject to the domestic budget constraint:

$$
w_{0 a}=M_{a}+n_{a} P_{a}
$$

where the end-of-period wealth of the domestic investor is:

$$
\widetilde{w}_{1 a}=\left(1+r_{f}\right) M_{a}+n_{a} \tilde{u}_{a}
$$

It is well-known that the expected utility of domestic investors can be expressed as $E\left(w_{l a} \mid I_{a}\right)-(0.5) R \operatorname{Var}\left(w_{l a} \mid I_{a}\right)$. We show (in Appendix I) that maximizing the expected utility with respect to $n_{a}$ leads to the following demand function for domestic investors:

$$
n_{a}\left(\phi, p_{a}\right)=\frac{\phi-\left(1+r_{f}\right) p_{a}}{R \sigma_{\varepsilon}^{2}}
$$

The demand for $A$ shares depends positively on the information $\phi$ and negatively on the price, the degree of risk-aversion, and the conditional volatility of returns. Because trading in domestic class shares is completely separated from trading in the foreign class shares, domestic shares are subject only to domestic market risk. In other words, the $A$ shares are priced as if the $B$ shares do not exist.

Let $P_{a}{ }^{*}(.,$.$) be some particular price function of \left(x_{a}, \phi\right)$ such that $u_{a}$ and $P_{a}{ }^{*}$ are jointly normally distributed (we will prove that such a price function exists). A foreign investor chooses $n_{b}$ to maximize

$$
\mathrm{E}\left[u\left(\widetilde{w}_{1 b}\right) \mid p_{b} ; P_{a}^{*}\right]
$$

subject to the foreign budget constraint: 


$$
w_{0 b}=M_{b}+n_{b} p_{b}+n_{c} p_{c}
$$

where the end-of-period wealth of the foreign investor is:

$$
\tilde{w}_{1 b}=\left(1+r_{f}\right) M_{b}+n_{b} \tilde{u}_{b}+n_{c} \tilde{u}_{c}
$$

We see that there is an additional component to the foreigners' budget constraint in (12) and (13), since they have the option to invest in the risky asset in their own market as well as Chinese $B$ shares. We show (in Appendix I) that the demand function $\left(n_{b}\right)$ of foreign investors for the $B$ shares is:

$$
n_{b}\left(p_{a}, p_{b}, n_{c} ; P_{a}^{*}\right)=\frac{E\left(\tilde{u}_{b} \mid P_{a}^{*}\left(\phi, x_{a}\right)=p_{a}\right)-\left(1+r_{f}\right) p_{b}-n_{c} \operatorname{RCov}\left(\tilde{u}_{b}, \tilde{u}_{c}\right)}{R \operatorname{Var}\left(\tilde{u}_{b} \mid P_{a}^{*}\left(\phi, x_{a}\right)=p_{a}\right)}
$$

The demands of foreign investors depend both on the actual price of $A$ and $B$ shares and the $A$ share price function, since the latter is informative about the expected return and variance of the $B$ shares. In addition, the demand for $B$ shares depends on the demand for $C$ shares and the covariance between the returns of the $B$ share market and the $C$-share market. If the covariance is negative, then investing in $B$ shares provides diversification benefits for foreign investors, and the $B$ share demand is higher as a result.

Finally, foreign investors' demand for the purely foreign asset $n_{c}$ is:

$$
n_{c}\left(p_{c}, n_{b}\right)=\frac{E\left(\tilde{u}_{c}\right)-\left(1+r_{f}\right) p_{c}-n_{b} \operatorname{RCov}\left(\tilde{u}_{b}, \tilde{u}_{c}\right)}{R \operatorname{Var}\left(\tilde{u}_{c}\right)}
$$

The equilibrium price distributions are functions $P_{a}\left(x_{a}, \phi\right), P_{b}\left(P_{a}\left(x_{a}, \phi\right), x_{b}, x_{c} ; P_{a}^{*}\right)$ and $P_{c}\left(x_{b}, x_{c}\right)$ such that, in each market, the demand for shares equals the supply available for every realization of $\phi$ and $x_{i}, i=a, b, c$. Note that $P_{a}{ }^{*}$ is the $A$ share price function conjectured by the foreign investors, whereas $P_{a}$ is the true $A$ share price function. In equilibrium, the particular 
price function $P_{a}{ }^{*}$ conjectured by foreign investors is, in fact, the function $P_{a}\left(x_{a}, \phi\right)$ determined in the $A$ share market.

Formally, the equilibrium price functions are determined by:

$$
\begin{aligned}
& n_{a}\left(\phi, P_{a}\right)=x_{a} \\
& n_{b}\left(P_{a}, P_{b}, x_{c} ; P_{a}^{*}\right)=x_{b} \\
& n_{c}\left(P_{c}, x_{b}\right)=x_{c}
\end{aligned}
$$

where we have suppressed the arguments in the price functions for brevity. ${ }^{8}$

$P_{a}\left(x_{a}, \phi\right)$ is a statistical equilibrium---i.e., over time foreign investors observe many realizations of $u_{a}$ and $P_{a}{ }^{*}$ to learn the joint distribution of $u_{a}$ and $P_{a}{ }^{*}$ and, consequently, the joint distribution of $u_{b}$ and $P_{a}{ }^{*}$. Based on this knowledge, they will trade and form expectations such that these joint distributions persist over time. We shall now prove that there exists an equilibrium price distribution $P_{a}{ }^{*}\left(x_{a}, \phi\right)$ such that $u_{a}$ and $P_{a}{ }^{*}$ are jointly normally distributed and, further, characterize this price distribution.

Proposition 1. 1) Suppose neither domestic nor foreign investors observe $\phi$ (i.e., information is symmetric). Then:

$$
\begin{aligned}
& P_{a 0}\left(x_{a}\right)=\frac{1}{\left(1+r_{f}\right)}\left\{E\left(\tilde{u}_{a}\right)-\operatorname{Rx} x_{a} \operatorname{Var}\left(\tilde{u}_{a}\right)\right\} \\
& P_{b 0}\left(x_{b}, x_{c}\right)=\frac{1}{\left(1+r_{f}\right)}\left\{E\left(\tilde{u}_{b}\right)-\operatorname{Rx} \operatorname{Var}\left(\tilde{u}_{b}\right)-\operatorname{Rx} \operatorname{Cov}\left(\tilde{u}_{b}, \tilde{u}_{c}\right)\right\}
\end{aligned}
$$

${ }^{8}$ In specifying (18), we have assumed that the demand for $C$ shares depends only on the supplies $x_{b}$ and $x_{c}$, and not on the $A$ share price function $P_{a}$. This is a reasonable assumption, since the information $\phi$ is specific to the domestic asset, and has no value in pricing the $C$ shares. 


$$
P_{c 0}\left(x_{b}, x_{c}\right)=\frac{1}{\left(1+r_{f}\right)}\left\{E\left(\tilde{u}_{c}\right)-R x_{c} \operatorname{Var}\left(\tilde{u}_{c}\right)-R x_{b} \operatorname{Cov}\left(\tilde{u}_{b}, \tilde{u}_{c}\right)\right\}
$$

where $P_{a 0}(.,),. P_{b 0}(.,$.$) and P_{c 0}(.,$.$) are the A, B$ and $C$ share price functions when domestic and foreign investors do not know $\phi$.

2) Suppose domestic investors observe $\phi$, but foreign investors do not. Then:

$$
\begin{aligned}
& \begin{aligned}
& P_{a}\left(\phi, x_{a}\right)= \frac{1}{\left(1+r_{f}\right)}\left\{\phi-R x_{a} \sigma_{\varepsilon}^{2}\right\} \\
& \begin{aligned}
P_{b}\left(P_{a}, x_{b}, x_{c} ; P_{a}^{*}\right)= & \frac{1}{\left(1+r_{f}\right)}\left\{E\left(\tilde{u}_{b} \mid P_{a}^{*}=P_{a}\left(\phi, x_{a}\right)\right)-\operatorname{Rx} \operatorname{Var}\left(\tilde{u}_{b} \mid P_{a}^{*}=P_{a}\left(\phi, x_{a}\right)\right)\right. \\
& \left.-R x_{c} \operatorname{Cov}\left(\tilde{u}_{b}, \tilde{u}_{c}\right)\right\}
\end{aligned} \\
& P_{c}\left(x_{b}, x_{c}\right)=P_{c 0}\left(x_{b}, x_{c}\right)
\end{aligned}
\end{aligned}
$$

The expressions for $\mathrm{E}\left(u_{b} \mid P_{a}{ }^{*}\right)$ and $\operatorname{Var}\left(u_{b} \mid P_{a}{ }^{*}\right)$ are derived in the appendix. The pricing equations (22) and (23), without the covariance term, are similar to those in noisy rational expectations model with asymmetric information, such as equations (A7) and (A10) in Grossman and Stiglitz (1980). Further, the pricing equation for the $C$ shares is the same whether there is informational asymmetry in the Chinese market or not. This is because there are no informational linkages between the foreign stock market and the Chinese stock market.

Let the random variable $z_{a}$, defined in (A13) of the appendix, be a linear transformation of $P_{a}$. Proposition 2 characterizes the conditions under which the $B$ share prices are at a discount or premium to the $A$ share prices.

Proposition 2. 1) Suppose $\operatorname{cov}\left(u_{b}, u_{c}\right)=0$. If :

$$
\frac{x_{b}}{x_{a}}>\frac{\operatorname{Var}\left(\tilde{z}_{a}\right)}{R^{2} \sigma_{\varepsilon}^{2} \operatorname{Var}\left(x_{a}\right) \operatorname{Var}(\phi)+\operatorname{Var}\left(\tilde{z}_{a}\right)}
$$


then, $\mathrm{E}\left(p_{a}\right)>\mathrm{E}\left(p_{b}\right)$.

2) Suppose domestic investors do not observe $\phi$ and $\operatorname{cov}\left(u_{b}, u_{c}\right)<0$. If $x_{a} \operatorname{var}\left(u_{a}\right) \geq$ $x_{b} \operatorname{var}\left(u_{b}\right)$, then $\mathrm{E}\left(p_{a 0}\right)<\mathrm{E}\left(p_{b 0}\right)$.

Consider part two of Proposition 2 first. Let $p_{a 0}$ and $p_{b 0}$ be particular realizations of the price functions when there is symmetric information. Note that (1), (2) and (3) imply that $\mathrm{E}\left(u_{a}\right)=\mathrm{E}\left(u_{b}\right)=\mathrm{E}(\phi)$. Then, from (19) and (20), the difference in the $A$ and $B$ share prices is:

$$
p_{a 0}-p_{b 0}=\frac{1}{\left(1+r_{f}\right)}\left\{\left[R\left\{x_{b} \operatorname{var}\left(u_{b}\right)-x_{a} \operatorname{var}\left(u_{a}\right)\right\}\right]+R x_{c} \operatorname{Cov}\left(\tilde{u}_{b}, \tilde{u}_{c}\right)\right\}
$$

Suppose $\operatorname{cov}\left(u_{b}, u_{c}\right)<0$ : i.e., diversification benefits foreign investors. If $x_{a} \operatorname{var}\left(u_{a}\right) \geq$ $x_{b} \operatorname{var}\left(u_{b}\right)$ (i.e., the supply of $A$ shares is higher than the supply of $B$ shares-true for our sample (appendix II); and domestic investors face at least as much idiosyncratic risk on the domestic asset as foreign investors $\left.{ }^{9}\right)$, then $\mathrm{E}\left(p_{a 0}\right)<\mathrm{E}\left(p_{b 0}\right)$. Thus, consistent with earlier models of market segmentation, the $B$ shares trade at a premium when there is no informational asymmetry and foreigners benefit from international diversification.

Now, consider part one of Proposition 2. Let $p_{a}$ and $p_{b}$ be particular realizations of the price functions when there is asymmetric information. From (22) and (23), we obtain the following relationship between the market prices of A and B shares:

$$
\begin{gathered}
p_{a}-p_{b}=\frac{1}{\left(1+r_{f}\right)}\left\{\left[\phi-E\left(\tilde{u}_{b} \mid P_{a}\left(x_{a}, \phi\right)=p_{a}\right)\right]+R\left[x_{b} \operatorname{var}\left(\tilde{u}_{b} \mid P_{a}\left(x_{a}, \phi\right)=p_{a}\right)-x_{a} \sigma_{\varepsilon}^{2}\right]\right. \\
\left.+\operatorname{Rx} x_{c} \operatorname{Cov}\left(\tilde{u}_{b}, \tilde{u}_{c}\right)\right\}
\end{gathered}
$$

From (27), whether $\mathrm{B}$ shares are traded above or below the price of $A$ shares is determined by: the information asymmetry effect (the first two terms in square brackets) and the

\footnotetext{
${ }^{9}$ This follows since, from (5), $\operatorname{var}\left(u_{a}\right) \geq \operatorname{var}\left(u_{b}\right)$ implies that $\sigma_{\varepsilon}^{2} \geq \operatorname{Var}(\gamma)$.
} 
diversification effect (the last term). If $\operatorname{Cov}\left(\widetilde{u}_{b}, \widetilde{u}_{c}\right)=0$, the relative prices of $A$ and $B$ shares are determined purely by the information asymmetry effect, which has two parts: the difference between the conditional expectations of future returns; and the difference between the conditional variances of future returns. The difference arises due to the difference in the conditioning information sets of domestic and foreign investors.

Letting $\operatorname{Cov}\left(\widetilde{u}_{b}, \tilde{u}_{c}\right)=0$, and taking expectations on both sides of (27), we show in Appendix I that the average difference in conditional expectations is zero, while the average difference in the conditional variances is positive, if (25) is satisfied. Hence, $\mathrm{E}\left(p_{a}\right)>\mathrm{E}\left(p_{b}\right)$. (25) is likely to be satisfied if the right hand side of the expression is small, which happens when the variance of the $A$ share price is large. In this case, the $A$ share price is relatively uninformative, and the information asymmetry problem is severe. Intuitively, relative to foreign investors, domestic investors form more precise estimates of the distribution of future returns, and thus require lower expected returns now.

\section{B. The Relative Pricing Model With Index Securities}

Without loss of generality, assume there are two $B$ stocks: $B_{1}$ and $B_{2}$. In addition, investors can trade in the $B$ share market an index security $I$, where the price of $I, p_{I}$, is the weighted average of the prices of stocks $B_{1}$ and $B_{2}$. In other words, $p_{I}=w_{1} p_{1}+w_{2} p_{2}$, where $w_{2}$ $=1-w_{1}, w_{i}>0$ is the weight and $p_{i}$ is the price of stock $B_{i}, i=1,2$. We continue to assume that the number of stocks is one in the $A$ and $C$ share markets.

In Subrahmanyam (1991) and Gorton and Pennacchi (1993), the index security has a lower return variance, and hence the market maker's loss to informed traders is smaller than 
when individual stocks are traded. As a result, uninformed traders reduce their losses to informed traders by trading an index security, or a basket of securities. It is interesting to see whether such a scenario holds in our model as well. Specifically, do foreign investors trade more $B$ shares, and is the $B$ share discount lower as a result of the $B$ stock index?

Let $u_{I}$ be the unknown future return and $n_{I}$ the number of shares bought or sold of the index security. Let $u_{i}$ be the future return of stock $B_{i}, i=1,2$. Note that the maximization problem for domestic investors does not change. Hence, the equilibrium price function in the $A$ share market is still given by $P_{a}$ in (22). The market clearing conditions are $n_{i}=x_{i}, i=1,2, a, c, I$. Proceeding as before, we can calculate, for each stock $B_{i}, i=1,2$, the equilibrium price function $P_{i}$ and the shares traded $n_{i}$ as follows:

$$
\begin{aligned}
n_{i}+w_{i} n_{I}= & \frac{E\left(\tilde{u}_{i} \mid P_{a}^{*}\left(\phi, x_{a}\right)=p_{a}\right)-\left(1+r_{f}\right) p_{i}-n_{c} \operatorname{RCov}\left(\tilde{u}_{i}, \tilde{u}_{c}\right)}{2 R \operatorname{Var}\left(\tilde{u}_{i} \mid P_{a}^{*}\left(\phi, x_{a}\right)=p_{a}\right)} \\
P_{i}\left(P_{a}, x_{i}, x_{c}, x_{I} ; P_{a}^{*}\right)= & \frac{1}{\left(1+r_{f}\right)}\left\{E\left(\tilde{u}_{i} \mid P_{a}^{*}=P_{a}\left(\phi, x_{a}\right)\right)-2 R\left(x_{i}+w_{i} x_{I}\right) \operatorname{Var}\left(\tilde{u}_{i} \mid P_{a}^{*}=P_{a}\left(x_{a}, \phi\right)\right)\right. \\
& \left.-R x_{c} \operatorname{Cov}\left(\tilde{u}_{i}, \tilde{u}_{c}\right)\right\}
\end{aligned}
$$

Proposition 3. The introduction of an index security on $B$ shares makes no difference to:

1) the total number of $B$ shares traded.

2) the price of a $B$ share stock.

At first sight, Proposition 3 might appear to contradict the results of Subrahmanyam (1991) and Gorton and Pennacchi (1993). This is not so. The difference between our model and those of the other authors is that the $A$ share and $B$ share markets are segmented. Since foreign and domestic investors do not trade together in the $B$ share market, the existence of the 
$B$ stock index makes no difference to the degree of informational asymmetry faced by foreign investors. The effect is merely to create another security in which the foreign wealth is invested in a proportional manner.

To clarify the above point, suppose that there are two $A$ stocks and an index on $A$ shares. Suppose, further, that domestic investors are allowed to trade individual $A$ stocks, but not the index, whereas foreign investors are allowed to trade the $A$ share index, but not the underlying stocks. In addition, foreign investors may trade individual $B$ share stocks. To simplify the model, assume there is only one $B$ stock and no $C$ stock. Our results do not depend on these assumptions.

Denote the two $A$ stocks: $A_{1}$ and $A_{2}$, and the $A$ share index security $I$, where the price of $I, p_{I}$, is the weighted average of the prices of stocks $A_{1}$ and $A_{2}$. As before, $p_{I}=w_{1} p_{1}+w_{2} p_{2}$, where $w_{2}=1-w_{l}, w_{i}$ is the weight and $p_{i}$ is the price of stock $A_{i}, i=1,2$. Let $u_{I}$ be the unknown future return and $n_{I}$ the number of shares bought or sold of the index security. Let $u_{i}$ be the future return of stock $A_{i}, i=1,2$. We calculate the price function $P_{b}$ and the demand $n_{b}$ of the $B$ shares, as follows:

$$
\begin{aligned}
n_{b}\left(p_{a}, p_{b}, n_{I} ; P_{a}^{*}\right)= & \frac{E\left(\tilde{u}_{b} \mid P_{a}^{*}=p_{a}\right)-\left(1+r_{f}\right) p_{b}-n_{I} \operatorname{RCov}\left(\tilde{u}_{b}, \tilde{u}_{I} \mid P_{a}^{*}=p_{a}\right)}{\operatorname{Rar}\left(\tilde{u}_{b} \mid P_{a}^{*}=p_{a}\right)} \\
P_{b}\left(P_{a}, x_{b}, x_{I} ; P_{a}^{*}\right)= & \frac{1}{\left(1+r_{f}\right)}\left\{E\left(\tilde{u}_{b} \mid P_{a}^{*}=P_{a}\left(\phi, x_{a}\right)\right)-\operatorname{Rx} \operatorname{Var}\left(\tilde{u}_{b} \mid P_{a}^{*}=P_{a}\left(\phi, x_{a}\right)\right)\right. \\
& \left.-R x_{I} \operatorname{Cov}\left(\tilde{u}_{b}, \tilde{u}_{I} \mid P_{a}^{*}=P_{a}\left(\phi, x_{a}\right)\right)\right\}
\end{aligned}
$$

Comparing (14) and (23) with (30) and (31), we see that, if $\operatorname{cov}\left(u_{b}, u_{I} \mid P_{a}\right)<0$, then investment in $B$ shares is higher and, further, the price of $B$ shares is also higher. In other words, 
if the $A$ share index allows foreign investors to hedge the risk of trading $B$ shares, they would be willing to invest more and pay a higher price for the $B$ shares.

Proposition 4. Suppose foreign investors could trade an index security on $A$ shares, but not the underlying stocks. If the return on the index security is negatively correlated with the $B$ share return, then, relative to the situation when no index security is available:

1) the total number of $B$ shares traded is higher.

2) the price of a $B$ share stock is higher.

\section{EMPIRICAL RELATIONSHIP BETWEEN CHINESE A AND B SHARE PRICES}

\section{A. $\quad$ Sample and Correlations Between Chinese and Foreign Markets}

Our sample consists of 39 firms issuing both $A$ and $B$ shares identified from the DATASTEAM database. ${ }^{10}$ Of these, 23 firms were listed on the SSE and the remaining 16 on the SZE. Our test period begins in January 1994, the month in which China unified the exchange rate system, in order to minimize any effects arising from the dual exchange rates in effect before that time. The listing dates of the $A$ and $B$ shares and the ownership structure of the sample firms are in Appendix II.

For each pair of class $A$ and $B$ shares, we collect daily prices and trading volume from the DATASTRRAM database. Since $A$ and $B$ shares are traded in different currencies, we convert the Shanghai $A$ share price into US\$ and the Shenzhen $A$ share price into HK\$, using the Renminbi/US\$ and Renminbi/HK\$ spot rates respectively. ${ }^{11}$ Similar to Bailey (1994), we

\footnotetext{
${ }^{10}$ Data for 19 other firms issuing both $A$ and $B$ shares were not available, because either their trading history was too short, or because there were too few $B$ share trades.

${ }^{11}$ The spot exchange rate (as quoted at the close of day) was used to convert daily $A$ share prices into the equivalent foreign currency prices (i.e., US\$ price for Shanghai $A$ share and HK\$ price for Shenzhen $A$ share).
} 
express the discount of the $B$ shares as a fraction of the $A$ share prices, i.e., the $B$ share price minus the $A$ share price, divided by the $A$ share price.

We also collect data on market indices for the Shanghai $A$ and $B$ shares and for the Shenzhen $A$ and $B$ shares. To analyze the relationship between the $B$ shares and foreign markets, we select representative indices from markets that are closely related to the Chinese market: Hang Seng index (HSI) for the Hong Kong stock market, Hang Seng Chinese Enterprises Index (HSCEI) for the overseas Chinese stocks, Nikkei 225 Index (NIKKEI) for the Japanese market, and S\&P 500 Index (S\&P) for the US market.

Table 2 reports the distribution of the daily average discount for $B$ shares from January 1994 to December 1996. Almost all $B$ shares experienced substantial price discounts in this period. The mean and median of the daily discount for the whole sample are 58.68 percent and 60.71 percent, respectively. The daily average discount for the Shanghai $B$ shares is 65.65 percent, higher than 48.71 percent for the Shenzhen $B$ shares. A time-series of average daily price discounts for all $B$ shares and separately for Shanghai and Shenzhen B shares are plotted in Figure 1.

Table 3 reports the bivariate return correlations among the $A$ and $B$ share indices, as well as the Hong Kong, Japanese and US market indices. The overall results suggest that the Chinese market is still isolated, even after the introduction of $B$ shares, and that the prices of $B$ shares are sensitive only to $A$ share prices and have little relationship to the foreign markets. The same

For our sample period, the mean and standard deviation of the exchange rate were 0.1181 (i.e., 100 Yuans = US\$11.81) and 0.0023 for US\$/Renminbi, and 0.9151 (i.e., 100 Yuan $=$ HK\$91.51) and 0.0163 for HK\$/Renminbi. Thus, the exchange rates were relatively stable during our sample period, which is not surprising since the HK\$ is pegged to the US\$ and the Yuan was stabilized at the official exchange rate. 
findings are reported in Bailey (1994). The correlation results indicate that the $B$ share discounts are unlikely to be affected by price change in the foreign stock markets.

Specifically, we find that the Shanghai $A$ share market is highly correlated with the Shenzhen $A$ share market (the correlation coefficient $\rho=0.7754$ ), and the Shanghai $B$ share market is positively related to the Shenzhen $B$ share market $(\rho=0.2885)$. Also, while the $B$ share markets show significant correlation with the $A$ share markets, they show little correlation with the Japanese and US markets. For example, while the correlation coefficients of SHAIB/SHAIA and SHAIB/HSCEI are positive and significant, the correlation coefficients for SHAIB/NIKKEI and SHAIB/S\&P are not different from zero. The Hong Kong market appears more correlated with the Shanghai $B$ share market than with the Shenzhen $B$ share market.

These results indicate that the relative pricing of Chinese $A$ and $B$ shares is not primarily related to the diversification benefits of foreign investors.

\section{B. Lead-Lag Relationship Between A and B Share Returns}

To shed light on the information asymmetry between $A$ and $B$ shares, we test whether $A$ share returns lead $B$ share returns. If both $A$ shares and $B$ shares react to the new information in the same manner, we would expect price movements in these two markets to be contemporaneously correlated. On the other hand, if one market reacts to information faster than the other market, we may observe a lead-lag relation.

We use the following functional form to study the lead-lag relationship between $A$ shares and $B$ shares, 


$$
R_{B, t}=d_{0}+\sum_{k=-3}^{3} d_{k} R_{A, t+k}+\varepsilon_{B, t}
$$

where $R_{B, t}$ are daily $B$ share returns for day $t$ and $R_{A, t+k}$ are the corresponding daily $A$ share returns for day $t+k$. The coefficients with negative subscripts $\left(d_{-3}, d_{-2}, d_{-1}\right)$ are lead coefficients--i.e., if these coefficients are significant, then current $B$ share returns are related to past $A$ share returns; hence, $A$ share returns lead $B$ share returns. Similarly, the positive subscripts $\left(d_{3}, d_{2}, d_{1}\right)$ are lag coefficients that indicate whether $A$ share returns lag $B$ share returns. Examination of the data indicates that three leads and three lags are appropriate.

Table 4 presents the estimation coefficients of the leads and lags for the entire sample. Table 5 reports the estimation results for two subsamples - the Shanghai and Shenzhen stock exchanges. Both tables report quartiles, minimum and maximum values of the estimated coefficients, together with the number of significant coefficients obtained. For example, $\mathrm{q}_{1}$ indicates the maximum lead or lag value in the first quartile for each coefficient. The $t$-statistics are indicated in parentheses.

For the whole sample in table 4 , the proportion of significant lead coefficients is about $36 \%$ for a one-day lead, and about $5 \%$ for a one-day lag. $F_{\text {lead }}$ and $F_{\text {lag }}$ are $F$-statistics that test whether the lead coefficients $\left(d_{-3}, d_{-2}, d_{-1}\right)$ and the lag coefficients $\left(d_{1}, d_{2}, d_{3}\right)$ are, respectively, jointly zero. According to the $F$-statistics, for 19 out of 39 stocks, the null hypothesis that all the lead coefficients are jointly zero is rejected. In the case of lag coefficients, the $F$-statistics reject the null hypothesis for only 6 stocks.

Consistent with Wo (1997), we find some evidence of two-way information flows between the $A$ share and $B$ share markets. However, we also find that, consistent with our 
information asymmetry hypothesis, $A$ share returns are more likely to lead $B$ share returns, on average, rather than the other way around. From table 5, for the Shanghai stock exchange, 6 (or 26 percent) of 23 stocks have significant one-day lead coefficients, with no stock having significant two-day lead coefficients. In contrast, no stock has a significant one-day lag coefficient, but 4 stocks have significant two-day lag coefficients. The null hypothesis is rejected for 8 stocks for the lead coefficients, and only 3 stocks for the lag coefficients.

A similar pattern is observed for the Shenzhen stock exchange. 50 percent of the stocks have significant lead coefficients for one-day lead, while only 12 percent of lag coefficients are significant for one-day lag. The $F$-statistics indicate that, for 11 out of 16 stocks, the null hypothesis that all the lead coefficients are jointly zero is rejected. In the case of lag coefficients, the $F$-statistics reject the null hypothesis for only 3 out of the 16 stocks in Shenzhen.

\section{Foreign Media Coverage Impact}

One way to analyze information asymmetries between domestic and foreign investors is to look at the impact of English media coverage. ${ }^{12}$ For $B$ share investors, the English media report is an important source of information, since firms with wide coverage in the media may be easier to monitor, reducing informational asymmetries between domestic and foreign investors. Hence, we conjecture that firms with greater media coverage will have lower price discounts for their $B$ shares compared to firms with lower publicity.

To measure the degree of the English media coverage, we count the number of times a firm is mentioned in the headline of an article reported in the English newspapers. Specifically,

\footnotetext{
${ }^{12}$ We thank Stephen Brown for this suggestion.
} 
we search the Wall Street Journal Index through the Dow Jones Information Retrieval Service for the years 1995 to 1996, and count all citations for each firm. Then we rank firms based upon the amount of news coverage and the magnitude of $B$ share discount, and compute the rank correlation between the two series.

Table 6 presents the results of the rank correlation tests. The rank correlations for Shanghai $B$ share and Shenzhen $B$ share are -0.3937 and -0.4813 , respectively. The p-values from the Pearson tests are significant (at the 10 per cent threshold level) for both Shanghai and Shenzhen $B$ shares separately. ${ }^{13}$ Thus, consistent with the information asymmetry hypothesis, the results show a negative relationship between number of the English news report and level of the price discounts.

\section{Cross-Sectional Tests of the Determinants of B Share Discounts}

Our theoretical model implies a relationship between the $A$ share and $B$ share prices, as given by (27). We first express (27) in a form amenable to empirical testing. Define $\Delta p=$ $\left(1+r_{f}\right)\left(p_{a^{-}} p_{b}\right)$. We show in the appendix that $\Delta p$ can be expressed as:

$$
\begin{aligned}
\Delta p= & \phi \frac{R^{2} \sigma_{\varepsilon}^{2} \operatorname{Var}\left(x_{a}\right)}{\operatorname{Var}(\phi)}-R \frac{\operatorname{Cov}\left(u_{a}, u_{b}\right)}{\operatorname{Var}\left(\tilde{z}_{a}\right)}\left(\frac{E(\phi)}{\operatorname{Var}(\phi)} R\left(\sigma_{\varepsilon}^{2}\right)^{2} \operatorname{Var}\left(x_{a}\right)-x_{b} \operatorname{Var}(\phi)\right) \\
& +R x_{b}\left[\operatorname{Var}\left(\tilde{u}_{b}\right)-\frac{x_{a}}{x_{b}} \sigma_{\varepsilon}^{2}\right]+R x_{c} \operatorname{Cov}\left(\tilde{u}_{b}, \tilde{u}_{c}\right)
\end{aligned}
$$

To test the model, we form empirical proxies for the right-hand side variables in (33) to capture the cross-sectional variation in the $B$ share discounts. Recall that $z_{a}$ is simply a linear transformation of the $A$ share price. We show in the appendix that $\Delta p$, the price discount on $B$

\footnotetext{
${ }^{13}$ The rank correlation was not significant for the whole sample, and therefore was not reported.
} 
shares, is: (1) positively related to domestic investors' private information $\phi$; (2) negatively related to $\left[\operatorname{Cov}\left(\tilde{u}_{b}, \tilde{u}_{a}\right) / \operatorname{Var}\left(\tilde{\mathrm{p}}_{\mathrm{a}}\right)\right]$; and (3) positively related to the variance of $B$ share returns $\operatorname{Var}\left(u_{b}\right)$. These three factors capture the effect of information asymmetry on the $B$ share price discount. In addition, the parameters $R, x_{a}, x_{b}$ capture additional effects due to investor risk aversion and the supplies of the $A$ and $B$ shares. (33) predicts that the price discount on $B$ shares is negatively related to the relative supply of $A$ shares $x_{a} / x_{b}$.

Intuitively, a high value of $\operatorname{Cov}\left(\tilde{u}_{b}, \tilde{u}_{a}\right)$ indicates that $A$ share returns are informative about $B$ share returns. A high value of $\operatorname{Var}\left(\tilde{\mathrm{p}}_{\mathrm{a}}\right)$ means that the price of $A$ shares is very noisy, which leads foreign investors to learn $\phi$ imprecisely. Thus, the degree of asymmetric information (and the $B$ share discount) are negatively related to $\left[\operatorname{Cov}\left(\tilde{u}_{b}, \tilde{u}_{a}\right) / \operatorname{Var}\left(\tilde{\mathrm{p}}_{\mathrm{a}}\right)\right]$, since a high value of the variable indicates that the $B$ shareholders obtain a lot of information about $\phi$ from observing the $A$ share price. Similarly, a high value of $\operatorname{Var}\left(u_{b}\right)$ is indicative that $A$ share price is a noisy indicator of $\phi$. Hence, the $B$ share discount is positively related to $\operatorname{Var}\left(u_{b}\right)$.

For empirical investigation, it is convenient to rewrite (33) in the following form. For stock $i, i=1, \ldots 39$, we write:

$$
D I S_{i}=a_{0}+a_{1} S B A_{\mathrm{i}}+a_{2} V A R B_{i}+a_{3} S B F_{i}+a_{4} I N F O_{i}+a_{5} R A B_{i}+\varepsilon_{\mathrm{i}}
$$

where

$D I S=$ the average daily discount of the $B$ share prices, where the daily discount for stock $i$ on day $t$ is $D_{i t}=\left(P_{a i t}-P_{b i t}\right) / P_{\text {ait }}$, with $P_{\text {ait }}$ and $P_{b i t}$ being the $A$ and $B$ share prices, respectively. $S B A=\operatorname{Cov}\left(\tilde{u}_{b}, \tilde{u}_{a}\right) / \operatorname{Var}\left(\tilde{p}_{a}\right)$, measuring the return sensitivity of the $B$ shares to the $A$ shares. For each stock with $A$ and $B$ shares, we calculate the sample covariance between their 
returns, and divide by the sample variance of the $A$ share prices. Since a higher value of $S B A$ indicates a lower degree of informational asymmetry, we predict $a_{1}$ to be negative.

$\operatorname{VARB}=\operatorname{Var}\left(u_{b}\right)$, the sample variance of the $B$ share returns. From (33), $a_{2}$ is expected to be positive.

$$
\operatorname{SBF}=\operatorname{Cov}\left(\tilde{u}_{b}, \tilde{u}_{c}\right) / \operatorname{Var}\left(\tilde{u}_{c}\right), \text { measuring the foreign market sensitivity of } B \text { share. The }
$$

foreign market portfolio is proxied by the S\&P 500 Index. ${ }^{14} S B F$ is derived by running, for each stock, a time-series regression of the $B$ share returns on the S\&P 500 Index returns. We expect $a_{3}$ to be negative.

$I N F O=$ the number of company citations in the Wall Street Journal index, as described earlier in section B. Since this variable is a proxy for the information variable $\phi$, we expect $a_{4}$ to be negative.

$R A B=$ the ratio of the number of $A$ shares outstanding over the number of $B$ shares outstanding. From (33), $a_{5}$ should be negative.

We also include firm size $(S I Z E)$ and an exchange dummy variable $(D)$ in the regression. SIZE is the market capitalization of the firm (i.e., the number of $A$ shares times the $A$ share price, plus the number of $B$ shares times the $B$ share price). SIZE is widely used to explain stock returns in the finance literature, and may act as another proxy for information asymmetry (for example, more analysts may follow larger firms). $D$ takes on the value 1 when the stock is traded on the Shanghai Stock Exchange, and zero on the Shenzhen Stock Exchange. From our earlier results, the $B$ share discounts are higher for Shanghai, and so we expect the dummy coefficient to be positive.

\footnotetext{
${ }^{14}$ We also use the Hang Seng index and Nikkei 225 index as alternative proxies of the foreign market portfolios. The results are similar to the S\&P 500 index, so we do not report the results in the paper.
} 
We estimate equation (34) using OLS. Table 7 summarizes the regression results. The reported $t$ values are corrected for heteroskedasticity, following the method of White (1980). Models 1-3 run the regression with different various subsets of our right-hand side variables. Model 1 uses the three model-based variables $S B A, V A R B$, and $S B F$, plus the exchange dummy, as explanatory variables. These variables together explain 40 percent of the variation in the $B$ share discounts. Adding the media coverage variable INFO (model 2) increases the adjusted $R$ square to 0.5. With SIZE included (model 3), the adjusted R-square is 0.58 .

The sign and significance of the coefficients are consistent in all models where they are used. The coefficients on $S B A$ and $S B F$ have the right signs (negative), but are not significant (except for the coefficient on $S B F$ in model 3). In contrast, the coefficient on $V A R B$ has the right sign (positive), and it is significant. The INFO variable and the exchange dummy are also significant, with the expected signs. SIZE is negative and significant, consistent with the findings of Bailey (1994).

Model 4 uses the entire set of explanatory variables, and explains 67 percent of the cross-sectional variance of the $B$ share discounts. All estimated coefficients have the right sign and are significant at the 1 percent level, except for the coefficients on $S B A$ and $S B F$, which are not significant. The two proxies for informational asymmetry, VARB and INFO, are significant and of the predicted signs. The negative and significant sign on SIZE also provide additional support for the information asymmetry hypothesis. Supply factors, proxied here by the relative supply of $A$ shares, is also important. The coefficient on this variable is negative and significant, consistent with the results of Chen and Su (1998). Overall, these results provide strong support for the information asymmetry hypothesis, as well as the predictions of our theoretical model. 
Although information asymmetry and market microstructure factors explain 67 percent

of the cross-sectional variance in the $B$ share discounts, the highly significant intercept term indicates that other variables may have added explanatory power. This is not surprising, given the large magnitude of the observed discounts in the $B$ share prices. Factors such as political and economic risks, foreign and domestic investor sentiments may also play roles in determining the $B$ share discounts. This is an avenue for future research.

\section{CONCLUSION}

Contrary to evidence that foreigner investors pay higher prices than domestic investors for local shares in other countries, we find that, in the Chinese stock markets, foreign class $B$ shares trade at an average discount of about 60 percent to the prices at which domestic $A$ shares trade. The usual diversification argument cannot explain this phenomenon.

We argue that one reason for the discount is that foreign investors have less information about local firms, relative to domestic investors. We develop a simple model, incorporating both asymmetric information and market segmentation, to explain the relative pricing of $A$ shares and $B$ shares. Our model predicts that, whether cross-listing leads to premia or discounts in trading of the foreign class shares, depends on the relative magnitudes of the information asymmetry effect and the diversification effect. The former effect leads to discounts for $B$ shares, while the latter effect implies a premia for $B$ shares. Our model identifies proxies for informational asymmetry, that we later use for our empirical tests. Finally, we show theoretically that introduction of an index security on the domestic $A$ shares, that can be traded by foreign investors, improves the liquidity of the $B$ share market. 
We show empirically that the information asymmetry hypothesis provides a significant, though partial, explanation as to why the $B$ shares consistently trade at lower prices than the $A$ shares. First, we find that $A$ share returns are more likely to lead $B$ share returns, rather than the reverse. Second, the $B$ share price discount on a stock is negatively related to its coverage in the English media. Finally, using a cross-sectional regression, we show that the $B$ share discount is significantly related to a proxy for informational asymmetry that is based on our model, and to the media coverage variable. Together with an exchange dummy, and a stock's size (i.e., its market capitalization), the information asymmetry proxies explain 67 per cent of the crosssectional variance of $B$ share price discounts.

Although we analyze the discount/premium in the Chinese stock markets, the results generalize to other cross-listed securities where informational asymmetry is a major factor. Of course, our focus on the information effect does not rule out other factors that could explain $B$ share discounts. For example, the $B$ share discounts could be caused by irrationally high domestic demand for the $A$ shares, or foreign investors' sentiment towards the Chinese stocks. The interest rate differential between the domestic and foreign markets is another factor that may influence the level of the discounts. Our model has abstracted from these factors, but they remain important areas for further study. 


\section{REFERENCES}

Alexander, G. J., C. Eun and S. Janakiramanan, 1987, "Asset Pricing and Dual Listing on Foreign Capital Markets: A Note,” Journal of Finance, 42, 151-158.

Amihud, Y. and H. Mendelson, 1986, "Asset Pricing and the Bid-Ask Spread," Journal of Financial Economics, 17, 223-249.

Bailey, W., 1994, "Risk and Return on China's New Stock Markets: Some Preliminary Evidence," Pacific-Basin Finance Journal, 2, 243-260.

Bailey, W. and J. Jagtiani, 1994, "Foreign Ownership Restrictions and Stock Prices in the Thai Capital Market," Journal of Financial Economics, 36, 57-87.

Basak, S., 1996, "An Intertemporal Model of International Capital Market Segmentation," Journal of Financial and Quantitative Analysis, 31, 161-188.

Bergstrom, K, K. Rydqvist and P. Sellin, 1993, “Asset Pricing with In- and Outflow Constraints: Theory and Empirical Evidence from Sweden," Journal of Business Finance and Accounting, 20, 856-869.

Black, F., 1974, "International Capital Market Equilibrium with Investment Barriers," Journal of Financial Economics, 1, 337-352.

, 1978, "The Ins and Outs of Foreign Investment," Financial Analyst Journal, 34, 17.

Brennan, M. J. and H. H. Cao, 1997, "International Portfolio Investment Flows," Journal of Finance, 52, 2, 1851-1880.

Chen, Y. and Y. Su, 1998, "An Examination into Market Segmentation in the Chinese Stock Market," Advances in Pacific Basin Financial Markets, 4, 49-70.

Diwan, I, V. Errunza and L. W. Senbet, 1993, "Country Funds for Emerging Economies," Portfolio Investment in Developing Countries, Ed. by Claessens and Gooptu, World Bank.

Domowitz, I, J. Glen and A. Madhavan, 1995, "International Cross-Listing, Ownership Rights and Order Flow Migration: Evidence form Mexico," unpublished working paper.

Errunza, V., and E. Losq, 1985, "International Asset Pricing under Mild Segmentation: Theory and Test," Journal of Finance, 40, 105-124. 
Eun, C. S., and S. Janakiramanan, 1986, "A Model of International Asset Pricing with A Constraint on the Foreign Equity Ownership," Journal of Finance, 41, 1-25-1037.

Foerster, S. R. and G. A. Karolyi, 1996, "The Effect of Market Segmentation and Illiquidity on Asset Prices: Evidence form Foreign Stocks Listing in the US," Dice Center working paper, Ohio State University.

Gorton, G. B. and G. G. Pennacchi, 1993, "Security Baskets and Index-linked Securities," Journal of Business, 66, 1-27.

Grossman, S. J. and J. E. Stiglitz, 1980, "On the Impossibility of Informationally Efficient Markets," American Economic Review, 70, 393-408.

Hietala, P. T. 1989, “Asset Pricing in Partially Segmented Markets: Evidence from the Finnish Market," Journal of Finance, 44, 697-718.

Kaye, L. and E. Cheng, 1992, "Babes in the Bourse," Far Eastern Economic Review, 16 July 1992, 48-50.

Merton, R., 1987, "A Simple Model of Capital Market Equilibrium with Incomplete Information," Journal of Finance, 42, 483-510.

Stapleton, R. C. and N. G. Subrahmanyam, 1977, "Market Imperfections, Capital Market Equilibrium and Corporation Finance," Journal of Finance, 32, 307-319.

Stulz, R. M., 1981, "On the Effects of Barriers to International Investment," Journal of Finance, 36, 923-934.

1983, "On the Determinants of Net Foreign Investment," Journal Finance, 38, $459,-468$.

Stulz, R. M., and W. Wasserfallen, 1995, "Foreign Equity Investment Restrictions, Capital Flight, and Shareholder Wealth Maximization: Theory and Evidence," Review of Financial Studies, 8, 1019-1057.

Subrahmanyam, A., 1991, "A Theory of Trading in Stock Index Futures," Review of Financial Studies, 4, 17-51.

Sze, J. W., 1993, “The Allure of B Shares," The China Business Review, January-February 1993, 42-48.

White, H. "A Heteroskedastic-Consistent Covariance Matrix Estimator and a Direct Test for Heteroskedasticity." Econometrica, 48 (1980), 817-838. 
Wo, C. S., 1997, "Chinese Dual-Class Equities: Price Differentials and Information Flows," Emerging Markets Quarterly, Summer 1997, 47-62.

\section{Appendix I}

Derivation of domestic investors' demand functions

For the domestic investors, their expected value and variance of the wealth are written as

$$
E\left\{\tilde{w}_{1 a} \mid \phi\right\}=\left(1+r_{f}\right) w_{0 a}+n_{a}\left[\phi-\left(1+r_{f}\right) p_{a}\right]
$$

and $\operatorname{Var}\left\{\tilde{w}_{1 a} \mid \phi\right\}=n_{a}^{2} \sigma_{\varepsilon}^{2}$.

The expected utility function of domestic investors can be expressed as:

$$
E\left\{u\left[\widetilde{w}_{1 a} \mid \phi\right]\right\}=E\left(\widetilde{w}_{1 a} \mid \phi\right)-\frac{R}{2} \operatorname{Var}\left(\widetilde{w}_{1 a} \mid \phi\right),
$$

Taking the derivative of (A2) with respect to $n_{a}$,

$$
\frac{\partial E\left(u\left(\widetilde{w}_{1 a}\right)\right)}{\partial n_{a}}=\phi-\left(1+r_{f}\right) p_{a}-R n_{a} \sigma_{\varepsilon}^{2} \quad .
$$

Set (A3) equal to zero to get (10).

Derivation of foreign investors' demand functions.

The expected utility function of foreign investors is:

$$
E\left\{u\left[\tilde{w}_{1 b} \mid \widetilde{P}_{a}^{*}\right]\right\}=E\left(\widetilde{w}_{1 b} \mid \widetilde{P}_{a}^{*}\right)-\frac{R}{2} \operatorname{Var}\left(\widetilde{w}_{1 b} \mid \widetilde{P}_{a}^{*}\right)
$$

where

$$
E\left\{\tilde{w}_{1 b} \mid \tilde{P}_{a}^{*}\right\}=\left(1+r_{f}\right) w_{0 b}+n_{b}\left[E\left(\tilde{u}_{b} \mid \tilde{P}_{a}^{*}\right)-\left(1+r_{f}\right) p_{b}\right]+n_{c}\left[E\left(\tilde{u}_{c}\right)-\left(1+r_{f}\right) p_{c}\right]
$$

and

$$
\operatorname{Var}\left\{\tilde{w}_{1 b} \mid \widetilde{P}_{a}^{*}\right\}=n_{b}^{2} \operatorname{Var}\left(\tilde{u}_{b} \mid \widetilde{P}_{a}^{*}\right)+n_{c}^{2} \operatorname{Var}\left(\tilde{u}_{c}\right)+2 n_{b} n_{c} \operatorname{Cov}\left(\tilde{u}_{b}, \tilde{u}_{c}\right)
$$

Taking the derivative of (A4) with respect to $n_{b}$ and $n_{c}$ :

$\frac{\partial E\left(u\left(\tilde{w}_{1 b}\right)\right)}{\partial n_{b}}=E\left(\tilde{u}_{b} \mid \tilde{P}_{a}^{*}\right)-\left(1+r_{f}\right) p_{b}-R\left\{n_{b} \operatorname{Var}\left(\tilde{u}_{b} \mid \tilde{P}_{a}^{*}\right)+n_{c} \operatorname{Cov}\left(\tilde{u}_{b}, \tilde{u}_{c}\right)\right\}$ 
$\frac{\partial E\left(u\left(\tilde{w}_{1 b}\right)\right)}{\partial n_{c}}=E\left(\tilde{u}_{c}\right)-\left(1+r_{f}\right) p_{c}-R\left\{n_{c} \operatorname{Var}\left(\tilde{u}_{c}\right)+n_{b} \operatorname{Cov}\left(\tilde{u}_{b}, \tilde{u}_{c}\right)\right\}$

Setting (A6) equal to zero and solving for $n_{b}$, we get (14). Setting (A7) equal to zero and solving for $n_{c}$ we get (15).

\section{Proof of Proposition 1}

1) Solving for $p_{a}$ from (10), we have:

$$
P_{a}\left(\phi, n_{a}\right)=\frac{1}{\left(1+r_{f}\right)}\left\{\phi-R n_{a} \sigma_{\varepsilon}^{2}\right\}
$$

If domestic investors do not observe $\phi$, then they know only the unconditional mean and variances of the $A$ share returns $\mathrm{E}\left(u_{a}\right)$ and $\operatorname{Var}\left(u_{a}\right)$. Using this fact, together with the condition that supply equals demand, we obtain (19).

Solving for $p_{b}$ from (14), we have:

$$
P_{b}\left(P_{a}^{*}, n_{b}, n_{c}\right)=\frac{1}{\left(1+r_{f}\right)}\left\{E\left(\widetilde{u}_{b} \mid P_{a}^{*}\right)-R n_{b} \operatorname{Var}\left(\tilde{u}_{b} \mid P_{a}^{*}\right)-\operatorname{Rn} n_{c} \operatorname{Cov}\left(\tilde{u}_{b}, \tilde{u}_{c}\right)\right\}
$$

If domestic investors do not observe $\phi$, then $P_{a}{ }^{*}$ is pure noise, and foreign investors know only the unconditional mean and variances of the $B$ share returns $\mathrm{E}\left(u_{b}\right)$ and $\operatorname{Var}\left(u_{b}\right)$. This fact, together with the market clearing conditions (17) and (18) give (20).

There is no asymmetric information in the $C$ share market. Hence, the form of the price function is the same as in (20), provided we switch subscript $b$ for subscript $c$, and vice versa, wherever they occur. This gives us (21).

2) Combining (A8) with the market clearing condition (16) gives us (22).

In (A9), make the substitution $P_{a}{ }^{*}=P_{a}$, where $P_{a}$ is the market clearing price function defined in (22). Using the market clearing conditions (17) and (18), gives us (23). Suppose $p_{a}$ 
is a particular realization of $P_{a}\left(x_{a}, \phi\right)$. To derive the conditional expectations and variances, we use the following formulae:

$$
E[\tilde{X} \mid \tilde{Y}=y]=E[\tilde{X}]+\frac{\operatorname{Cov}(\tilde{X}, \tilde{Y})}{\operatorname{Var}(\tilde{Y})}(y-E[\tilde{Y}])
$$

and $\quad \operatorname{Var}[\tilde{X} \mid \tilde{Y}=y]=\operatorname{Var}[\tilde{X}]-\frac{[\operatorname{Cov}(X, Y)]^{2}}{\operatorname{Var}(Y)}$.

We note that $\mathrm{E}(\phi)=\mathrm{E}\left(u_{a}\right)=\mathrm{E}\left(u_{b}\right)$. Then, from (A10), (1), (2) and (22) we obtain:

$$
\begin{aligned}
& E\left[\tilde{u}_{b} \mid P_{a}\left(x_{a}, \phi\right)=p_{a}\right]=E[\phi]+\frac{1}{1+r_{f}} \frac{\operatorname{Var}(\phi)}{\operatorname{Var}\left(\tilde{P}_{a}\right)}\left(p_{a}-\frac{E[\phi]-R \sigma_{\varepsilon}^{2} E\left[\tilde{x}_{a}\right]}{1+r_{f}}\right) \\
& \operatorname{Var}\left[\tilde{u}_{b} \mid P_{a}\left(x_{a}, \phi\right)=p_{a}\right]=\operatorname{Var}\left[\tilde{u}_{b}\right]-\left(\frac{1}{1+r_{f}}\right)^{2} \frac{[\operatorname{Var}(\phi)]^{2}}{\operatorname{Var}\left(\tilde{P}_{a}\right)} .
\end{aligned}
$$

(24) follows from the fact that there is no asymmetric information in the $C$ share market.

\section{Proof of Proposition 2}

Define the random variable $z_{a}$ as follows:

$$
\tilde{z}_{a}=\left(1+r_{f}\right) \widetilde{P}_{a}+R \sigma_{\varepsilon}^{2} E\left[\tilde{x}_{a}\right]
$$

Thus, $z_{a}$ is a linear transformation of $P_{a}$.

1) Consider (27). From (A11), the difference in conditional expectations is:

$$
\phi-E\left[\tilde{u}_{b} \mid P_{a}\left(x_{a}, \phi\right)=p_{a}\right]=\phi-E[\tilde{\phi}]-\frac{1}{1+r_{f}} \frac{\operatorname{Var}(\phi)}{\operatorname{Var}\left(\tilde{P}_{a}\right)}\left(p_{a}-\frac{E[\tilde{\phi}]-R \sigma_{\varepsilon}^{2} E\left[\tilde{x}_{a}\right]}{1+r_{f}}\right)
$$

Using (A13), we can rewrite (A14) as follows:

$$
\phi-E\left[\tilde{u}_{b} \mid P_{a}\left(x_{a}, \phi\right)=p_{a}\right]=\phi-E[\tilde{\phi}]-\frac{\operatorname{Var}(\phi)}{\operatorname{Var}\left(\tilde{z}_{a}\right)}\left(z_{a}-E[\tilde{\phi}]\right)
$$

From (A12) and (A13), the difference in the conditional variances is:

$$
x_{b} \operatorname{Var}\left[\tilde{u}_{b} \mid P_{a}\left(x_{a}, \phi\right)=p_{a}\right]-x_{a} \sigma_{\varepsilon}^{2}=x_{b} \operatorname{Var}\left[\tilde{u}_{b}\right]-x_{b} \frac{[\operatorname{Var}(\phi)]^{2}}{\operatorname{Var}\left(\tilde{z}_{a}\right)}-x_{a} \sigma_{\varepsilon}^{2} .
$$

We assume $\operatorname{Var}\left(u_{a}\right)=\operatorname{Var}\left(u_{b}\right)$-i.e., the unconditional variances of $A$ share and $B$ share returns are equal. This is a reasonable assumption, since the underlying asset is the same. We 
note that $\operatorname{Var}\left(u_{a}\right)=\operatorname{Var}(\phi)+\sigma_{\varepsilon}^{2}$; and, further, $\operatorname{Var}\left(z_{a}\right)=\operatorname{Var}(\phi)+\left(\operatorname{R\sigma }_{\varepsilon}{ }^{2}\right)^{2} \operatorname{Var}\left(x_{a}\right)$. Using these facts, together with our assumption, we can rewrite (A16) as follows.

$$
x_{b} \operatorname{Var}\left[\tilde{u}_{b} \mid P_{a}\left(x_{a}, \phi\right)=p_{a}\right]-x_{a} \sigma_{\varepsilon}^{2}=\sigma_{\varepsilon}^{2}\left[x_{b} \frac{R^{2} \sigma_{\varepsilon}^{2} \operatorname{Var}(\phi) \operatorname{Var}\left(x_{a}\right)}{\operatorname{Var}\left(\tilde{z}_{a}\right)}+x_{b}-x_{a}\right]
$$

The expectation of (A15) is zero because $\mathrm{E}\left(\mathrm{z}_{a}\right)=\mathrm{E}(\phi)$. The expectation of (A17) is positive if the condition in Proposition 2 is satisfied. Thus, $\mathrm{E}\left(p_{a}\right)>\mathrm{E}\left(p_{b}\right)$.

\section{Derivation of foreign investors' demand functions with index securities}

The budget constraints of the foreign investors are:

$$
\begin{gathered}
w_{0 b}=M_{b}+\sum_{i=1}^{2} n_{i} p_{i}+n_{I} p_{I}+n_{c} p_{c} \\
=M_{b}+\sum_{i=1}^{2}\left(n_{i}+w_{i} n_{I}\right) p_{i}+n_{c} p_{c} \\
\tilde{w}_{1 b}=\left(1+r_{f}\right) M_{b}+\sum_{i=1}^{2}\left(n_{i}+w_{i} n_{I}\right) \tilde{u}_{i}+n_{c} \tilde{u}_{c}
\end{gathered}
$$

The expected utility function of foreign investors is still (A4) with:

$E\left\{\tilde{w}_{1 b} \mid \widetilde{P}_{a}^{*}\right\}=\left(1+r_{f}\right) w_{0 b}+\sum_{i=1}^{2}\left(n_{i}+w_{i} n_{I}\right)\left[E\left(\tilde{u}_{i} \mid \tilde{P}_{a}^{*}\right)-\left(1+r_{f}\right) p_{i}\right]+n_{c}\left[E\left(\tilde{u}_{c}\right)-\left(1+r_{f}\right) p_{c}\right]$

and

$$
\begin{aligned}
\operatorname{Var}\left\{\tilde{w}_{1 b} \mid \widetilde{P}_{a}^{*}\right\}= & \sum_{i=1}^{2}\left(n_{i}+w_{i} n_{I}\right)^{2} \operatorname{Var}\left(\tilde{u}_{i} \mid \widetilde{P}_{a}^{*}\right)+n_{c}^{2} \operatorname{Var}\left(\tilde{u}_{c}\right) \\
& +2 n_{c} \operatorname{Cov}\left(\tilde{u}_{i}, \tilde{u}_{c}\right) \sum_{i=1}^{2}\left(n_{i}+w_{i} n_{I}\right) \\
& +2 \operatorname{Cov}\left(\tilde{u}_{1}, \tilde{u}_{2}\right)\left(n_{1}+w_{1} n_{I}\right)\left(n_{2}+w_{2} n_{I}\right)
\end{aligned}
$$

Substituting (A20) in (A4) and then taking the derivative with respect to $n_{i}$ gives us (28). Solving (28) for $p_{i}$ and substituting the market clearing conditions $x_{i}=n_{i}, i=1,2, I, c$, gives us (29). 


\section{Proof of Proposition 3}

Suppose there were no index securities. Then the demand $n_{i}$ for security $i$ by the foreign investor is given by:

$$
n_{i}=\frac{E\left(\tilde{u}_{i} \mid \widetilde{P}_{a}\right)-\left(1+r_{f}\right) p_{i}-n_{c} R \operatorname{Cov}\left(\widetilde{u}_{i}, \tilde{u}_{c}\right)}{2 \operatorname{Rar}\left(\widetilde{u}_{i} \mid \widetilde{P}_{a}\right)}
$$

Note that the right-hand-sides of both (28) and (A21) are independent of $n_{I}$ and $p_{I}$.

Thus, the total investment in $B$ shares, which is $\sum_{i=1}^{2}\left(n_{i}+w_{i} n_{I}\right)$ with the index security and $\sum_{i=1}^{2}\left(n_{i}\right)$ without the index security, is the same. Hence, from (29) and the market clearing condition, the price levels $p_{i}$ is the same also.

\section{Proof of Proposition 4}

The budget constraints of the foreign investors are:

$$
\begin{aligned}
& w_{0 b}=M_{b}+n_{b} p_{b}+n_{I} p_{I} \\
& \tilde{w}_{1 b}=\left(1+r_{f}\right) M_{b}+n_{I} \tilde{u}_{I}+n_{b} p_{b}
\end{aligned}
$$

The expected utility function of foreign investors is still (A4) with:

$$
E\left\{\widetilde{w}_{1 b} \mid \widetilde{P}_{a}^{*}\right\}=\left(1+r_{f}\right) w_{0 b}+n_{b}\left[E\left(\widetilde{u}_{b} \mid \widetilde{P}_{a}^{*}\right)-\left(1+r_{f}\right) p_{b}\right]+n_{I}\left[E\left(\widetilde{u}_{I} \mid \widetilde{P}_{a}^{*}\right)-\left(1+r_{f}\right) p_{I}\right]
$$

and

$$
\operatorname{Var}\left\{\widetilde{w}_{1 b} \mid \tilde{P}_{a}^{*}\right\}=n_{b}{ }^{2} \operatorname{Var}\left(\widetilde{u}_{b} \mid \tilde{P}_{a}^{*}\right)+n_{I}^{2} \operatorname{Var}\left(\widetilde{u}_{I}\right)+2 n_{b} n_{I} \operatorname{Cov}\left(\tilde{u}_{b}, \tilde{u}_{I}\right)
$$

Substituting (A24) in (A4) and then taking the derivative with respect to $n_{b}$ gives us (30). Solving (30) for $p_{b}$ and substituting the market clearing conditions $x_{i}=n_{i}, i=b, I$ gives (31).

\section{Derivation of Equation (33)}

From (27), (A15) and (A16), we get: 


$$
\begin{aligned}
& \Delta p=\phi-E(\phi)-\frac{\operatorname{Var}(\phi)}{\operatorname{Var}\left(z_{a}\right)}\left(z_{a}-E(\phi)\right)+R\left[x_{b} \operatorname{Var}\left(u_{b}\right)-x_{b} \frac{(\operatorname{Var}(\phi))^{2}}{\operatorname{Var}\left(z_{a}\right)}-x_{a} \sigma_{\varepsilon}^{2}\right]+R x_{c} \operatorname{Cov}\left(u_{b}, u_{c}\right) \\
= & \phi-E(\phi) \frac{\left(R \sigma_{\varepsilon}^{2}\right)^{2} \operatorname{Var}\left(x_{a}\right)}{\operatorname{Var}\left(z_{a}\right)}-\frac{\operatorname{Var}(\phi)}{\operatorname{Var}\left(z_{a}\right)}\left(z_{a}-R x_{b} \operatorname{Var}(\phi)\right)+R x_{b}\left[\operatorname{Var}\left(u_{b}\right)-\frac{x_{a}}{x_{b}} \sigma_{\varepsilon}^{2}\right]+R x_{c} \operatorname{Cov}\left(u_{b}, u_{c}\right) \\
= & \phi\left[1-\frac{\operatorname{Var}(\phi)}{\operatorname{Var}\left(z_{a}\right)}\right]-R \frac{\operatorname{Var}(\phi)}{\operatorname{Var}\left(z_{a}\right)}\left[E(\phi) R \frac{\left(\sigma_{\varepsilon}^{2}\right)^{2} \operatorname{Var}\left(x_{a}\right)}{\operatorname{Var}(\phi)}-x_{b} \operatorname{Var}(\phi)\right] \\
& +R x_{b}\left[\operatorname{Var}\left(u_{b}\right)-\frac{x_{a}}{x_{b}} \sigma_{\varepsilon}^{2}\right]+R x_{c} \operatorname{Cov}\left(u_{b}, u_{c}\right)
\end{aligned}
$$

The third equality in (A25) follows from the definitions of $P_{a}$ and $z_{a}$ in (22) and (A13). (33) follows directly from (A25) by noting that $\operatorname{Var}\left(z_{a}\right)=\operatorname{Var}(\phi)+\left(R \sigma_{\varepsilon}{ }^{2}\right)^{2} \operatorname{Var}\left(x_{a}\right)$ and that $\operatorname{Var}(\phi)=\operatorname{Cov}\left(u_{a}, u_{b}\right)$.

The signs of the coefficients are established as follows. From (33), the coefficient on $\phi$ is clearly positive. The coefficient on $\operatorname{Var}(\phi) / \operatorname{Var}\left(z_{a}\right)$ is also positive if $\operatorname{Var}(\phi)$ is small relative to $\sigma_{\varepsilon}{ }^{2}$. This is likely to be the case, since $\operatorname{Var}(\phi)$ is the variance in the news (such as media citations), whereas $\sigma_{\varepsilon}^{2}$ is the variance in the idiosyncratic component of the $A$ share returns. 


\section{Appendix II}

Dual Listed $A$ and $B$ shares Included in the Sample

This table reports the dual listed class $A$ and class $B$ shares in the sample. Class $A$ shares are traded exclusively for domestic investors while class $B$ shares are traded exclusively for foreigners. A total of 39 companies comprise our sample: 23 firms are listed on the Shanghai Security Exchange (SSE), and 16 firms are listed on the Shenzhen Stock Exchange (SZE).

\begin{tabular}{|c|c|c|c|c|c|c|}
\hline \multirow[t]{2}{*}{ Company Name } & \multicolumn{2}{|c|}{ Listing Date } & \multicolumn{3}{|c|}{ A Shares (millions) } & \multirow{2}{*}{$\begin{array}{l}\text { B Shares } \\
\text { (millions) }\end{array}$} \\
\hline & Class A & $\overline{\text { Class B }}$ & State & Legal & Public & \\
\hline \multicolumn{7}{|l|}{ Listed on the SSE: } \\
\hline Auto Insts & $03 / 24 / 94$ & $04 / 29 / 94$ & 174 & 11 & 24 & 77 \\
\hline Dazhong Taxi & 08/07/92 & $07 / 22 / 92$ & 56 & 16 & 13 & 78 \\
\hline Diese Engine & $03 / 11 / 94$ & $12 / 28 / 93$ & 241 & 0 & 21 & 132 \\
\hline Erfangji & $03 / 27 / 92$ & 07/01/92 & 218 & 0 & 64 & 211 \\
\hline Friendship & $02 / 04 / 94$ & $01 / 05 / 94$ & 39 & 6 & 8 & 5 \\
\hline Goods \& Mats & $02 / 04 / 94$ & $03 / 30 / 94$ & 132 & 9 & 11 & 55 \\
\hline Haixin & $04 / 04 / 94$ & $12 / 08 / 93$ & 0 & 110 & 13 & 87 \\
\hline Hero & $03 / 11 / 94$ & $12 / 28 / 93$ & 75 & 8 & 13 & 45 \\
\hline Ind. Sewng & $03 / 11 / 94$ & $01 / 19 / 94$ & 97 & 10 & 12 & 75 \\
\hline Jinjiang Hotel & $06 / 07 / 93$ & $10 / 18 / 93$ & 0 & 220 & 26 & 101 \\
\hline Jinqiao Trd Zone & $03 / 26 / 93$ & $05 / 31 / 93$ & 240 & 30 & 75 & 143 \\
\hline Lianhua Fibre & $10 / 13 / 92$ & $09 / 28 / 93$ & 0 & 122 & 9 & 36 \\
\hline Lujiazui Dev. & $06 / 28 / 93$ & $11 / 25 / 94$ & 440 & 30 & 63 & 200 \\
\hline Narcissus Elec. & $01 / 06 / 93$ & $11 / 10 / 94$ & 0 & 196 & 17 & 110 \\
\hline Phonenix Bicycle & $10 / 08 / 93$ & $11 / 19 / 93$ & 243 & 11 & 22 & 110 \\
\hline Refrig Compr. & $11 / 16 / 92$ & $01 / 18 / 93$ & 124 & 46 & 15 & 138 \\
\hline Rubber Belt & 08/28/92 & $07 / 28 / 92$ & 44 & 6 & 6 & 33 \\
\hline Sanmao Textiles & $11 / 08 / 93$ & $12 / 31 / 93$ & 49 & 7 & 10 & 33 \\
\hline Shangling & $02 / 24 / 94$ & $01 / 31 / 94$ & 211 & 0 & 21 & 94 \\
\hline Steel Tube & $03 / 11 / 94$ & $03 / 15 / 94$ & 150 & 1 & 13 & 88 \\
\hline Vacuum Electrn & $12 / 19 / 90$ & $02 / 21 / 92$ & 237 & 0 & 133 & 159 \\
\hline Waigaoqiao Zone & $05 / 04 / 93$ & $07 / 26 / 93$ & 360 & 45 & 19 & 165 \\
\hline Wing Sung & 08/20/92 & $07 / 22 / 92$ & 52 & 8 & 6 & 30 \\
\hline \multicolumn{7}{|l|}{ Listed on the SZE: } \\
\hline Foshan Elec \& Ltg & $11 / 23 / 93$ & 08/08/95 & 43 & 26 & 30 & 50 \\
\hline Guangdong Pwr. & $11 / 26 / 93$ & 07/03/95 & 427 & 86 & 98 & 213 \\
\hline Jiangling Auto & $12 / 01 / 93$ & $10 / 18 / 95$ & 0 & 401 & 117 & 174 \\
\hline China Bicycles & $03 / 31 / 92$ & $03 / 31 / 92$ & 0 & 224 & 76 & 178 \\
\hline Chiwan & $05 / 05 / 93$ & $05 / 05 / 93$ & 0 & 224 & 50 & 106 \\
\hline Huafa Eltn & $04 / 28 / 92$ & $04 / 28 / 92$ & 0 & 153 & 32 & 77 \\
\hline Petrochem Ind. & $05 / 06 / 92$ & $06 / 05 / 92$ & 164 & 54 & 51 & 32 \\
\hline Konka Elt. & $03 / 27 / 92$ & $03 / 27 / 92$ & 0 & 182 & 60 & 78 \\
\hline Prop. \& Res Dev. & 03/10/92 & $03 / 30 / 92$ & 294 & 59 & 89 & 55 \\
\hline
\end{tabular}




\begin{tabular}{lllrrrr} 
Textile & $08 / 15 / 94$ & $08 / 15 / 94$ & 90 & 0 & 18 & 27 \\
Fiyta & $06 / 03 / 93$ & $06 / 03 / 93$ & 0 & 72 & 33 & 32 \\
Gintian Inds & $04 / 01 / 91$ & $06 / 29 / 93$ & 0 & 55 & 64 & 38 \\
Hainan Pearl Rvr & $12 / 21 / 92$ & $06 / 30 / 95$ & 0 & 206 & 113 & 57 \\
Shenbao Ind. & $10 / 12 / 92$ & $10 / 12 / 92$ & 83 & 8 & 25 & 21 \\
Vanke & $01 / 28 / 89$ & $05 / 28 / 93$ & 27 & 30 & 156 & 64 \\
Vct Onward Tex & $06 / 16 / 92$ & $06 / 16 / 92$ & 0 & 122 & 19 & 26 \\
\hline
\end{tabular}




\section{Table 1. Chinese Class $A$ and Class $B$ Share Markets}

This table presents information on the Chinese stock markets: the Shanghai Securities Exchange (SSE) and the Shenzhen Stock Exchange (SZE). All $A$ and $B$ shares must be listed on either of the two exchanges. Trading in $A$ shares is in Renminbi (i.e., the Chinese currency), while trading in $B$ shares is in US\$ on the SSE and in HK\$ on the SZE. The number of listed $A$ and $B$ shares are reported as of the end of 1996.

\begin{tabular}{|c|c|c|c|c|}
\hline Investors Group & $\begin{array}{l}\text { Investment } \\
\text { Opportunity Set }\end{array}$ & Currency & $\begin{array}{c}\text { Number of } \\
\text { Stocks Listed }\end{array}$ & Location \\
\hline Chinese Citizens & Class $A$ shares & Renminbi & $\begin{array}{l}287 \\
227 \\
\end{array}$ & $\begin{array}{l}\text { SSE } \\
\text { SZE }\end{array}$ \\
\hline \multirow[t]{2}{*}{ Foreigners } & Class $B$ shares & $\begin{array}{l}\text { US\$ } \\
\text { HK\$ }\end{array}$ & $\begin{array}{l}42 \\
43\end{array}$ & $\begin{array}{l}\text { SSE } \\
\text { SZE }\end{array}$ \\
\hline & Foreign stocks & & & Foreign Stock Exchange \\
\hline
\end{tabular}

Table 2. Distribution of the Daily Average Price Discounts for $B$ Shares

This table reports the daily average discounts for $B$ shares from the sample of 39 firms for the period January 1994 to December 1996. The average discounts for $B$ shares are calculated as the daily mean of $D_{i t}=\left(P_{a i t}-P_{b i t}\right) / P_{a i t}$, where, for stock $i$ on day $t, P_{a i t}$ and $P_{b i t}$ are the $A$ and $B$ share prices, respectively.

\begin{tabular}{crrr}
\hline $\begin{array}{r}\text { Daily Average } \\
\text { Discounts }\end{array}$ & $\begin{array}{r}\text { Shanghai (SSE) } \\
B \text { shares } \\
(\mathrm{n}=23)\end{array}$ & $\begin{array}{r}\text { Shenzhen (SZE) } \\
\text { s shares } \\
(\mathrm{n}=16)\end{array}$ & $\begin{array}{r}\text { Whole Sample } \\
(\mathrm{n}=39)\end{array}$ \\
\hline & & & \\
$0<\mathrm{D} \leq 20 \%$ & 0 & 0 & 0 \\
$20<\mathrm{D} \leq 40 \%$ & 1 & 5 & 6 \\
$40<\mathrm{D} \leq 60 \%$ & 7 & 6 & 13 \\
$60<\mathrm{D} \leq 80 \%$ & 12 & 5 & 3 \\
$80<\mathrm{D} \leq 100 \%$ & 3 & 0 & 58.68 \\
Mean & 65.62 & 48.71 & 60.71 \\
Median & 64.88 & 48.75 & \\
\hline
\end{tabular}




\section{Table 3. Return Correlations among Chinese and Foreign Markets}

The table reports the pairwise return correlations between Chinese and foreign market indices. The representative market indices are the Shanghai $A$ share index (SHAIA), the Shanghai $B$ share index (SHAIB), the Shenzhen $A$ share index (SZHENA), the Shenzhen $B$ share index (SZHENB), the Hang Seng Chinese Enterprise Index (HSCEI), the Hang Seng Index (HSI), the S\&P 500 index (S\&P), and the Nikkei 225 Index (NIKKEI). p-values are in parentheses.

\begin{tabular}{|c|c|c|c|c|c|c|c|c|}
\hline & SHAIA & SHAIB & SZHENA & SZHENB & HSCEI & HSI & $\mathrm{S} \& \mathrm{P}$ & NIKKEI \\
\hline SHAIA & 1.0000 & $\begin{array}{c}0.1578 \\
(0.0001)\end{array}$ & $\begin{array}{c}0.7754 \\
(0.0001)\end{array}$ & $\begin{array}{c}0.1253 \\
(0.0014)\end{array}$ & $\begin{array}{c}0.0650 \\
(0.0974)\end{array}$ & $\begin{array}{l}-0.0007 \\
(0.9861)\end{array}$ & $\begin{array}{l}-0.0070 \\
(0.8581)\end{array}$ & $\begin{array}{l}-0.0162 \\
(0.6796)\end{array}$ \\
\hline SHAIB & & 1.0000 & $\begin{array}{c}0.1952 \\
(0.0001)\end{array}$ & $\begin{array}{c}0.2885 \\
(0.0001)\end{array}$ & $\begin{array}{c}0.2409 \\
(0.0001)\end{array}$ & $\begin{array}{c}0.1978 \\
(0.0001)\end{array}$ & $\begin{array}{l}-0.0795 \\
(0.0427)\end{array}$ & $\begin{array}{c}0.0168 \\
(0.6696)\end{array}$ \\
\hline SZHENA & & & 1.0000 & $\begin{array}{c}0.0887 \\
(0.0237)\end{array}$ & $\begin{array}{c}0.0698 \\
(0.0752)\end{array}$ & $\begin{array}{c}0.0387 \\
(0.3247)\end{array}$ & $\begin{array}{l}-0.0239 \\
(0.5434)\end{array}$ & $\begin{array}{l}-0.0038 \\
(0.9227)\end{array}$ \\
\hline SZHENB & & & & 1.0000 & $\begin{array}{c}0.0130 \\
(0.7413)\end{array}$ & $\begin{array}{c}0.0094 \\
(0.8102)\end{array}$ & $\begin{array}{l}-0.0427 \\
(0.2763)\end{array}$ & $\begin{array}{c}0.0409 \\
(0.2980)\end{array}$ \\
\hline HSCEI & & & & & 1.0000 & $\begin{array}{c}0.5895 \\
(0.0001)\end{array}$ & $\begin{array}{c}0.0534 \\
(0.1739)\end{array}$ & $\begin{array}{c}0.1629 \\
(0.0001)\end{array}$ \\
\hline HSI & & & & & & 1.0000 & $\begin{array}{c}0.0530 \\
(0.1770)\end{array}$ & $\begin{array}{c}0.2015 \\
(0.0001)\end{array}$ \\
\hline$S \& P$ & & & & & & & 1.0000 & $\begin{array}{c}0.0204 \\
(0.6029)\end{array}$ \\
\hline NIKKEI & & & & & & & & 1.0000 \\
\hline
\end{tabular}




\section{Table 4. Lead-lag Relationship Between $A$ and $B$ Share Returns For the Whole Sample}

The table reports results for the following regression:

$$
R_{B, t}=d_{0}+\sum_{k=-3}^{3} d_{k} R_{A, t+k}+\varepsilon_{B, t}
$$

where $R_{B, t}$ is the $B$ share return on day $t$, and $R_{A, t+k}$ is the $A$ share return on day $t+k$. For $k<0, \mathrm{~N}^{*}$ is number of stocks for which $d_{k}$ is significant at the $10 \%$ level. $\mathrm{F}_{\text {lead }}$ is an F-statistic that tests whether $d_{-1}=$ $d_{-2}=d_{-3}=0 . \mathrm{F}_{\text {lag }}$ is an F-statistic that tests whether $d_{1}=d_{2}=d_{3}=0$. There are 39 stocks in the sample.

\begin{tabular}{|c|c|c|c|c|c|c|c|c|}
\hline Coefficient & mean & $\min$ & $\mathrm{q}_{1}$ & $\begin{array}{c}\text { Median } \\
\text { Quartiles }\end{array}$ & $\mathrm{q}_{3}$ & Max & $\mathrm{N}^{*}$ & $\%$ \\
\hline $\mathrm{d}_{-3}$ & $\begin{array}{l}0.0207 \\
(0.482)\end{array}$ & $\begin{array}{l}-0.0616 \\
(-1.853)\end{array}$ & $\begin{array}{l}-0.0160 \\
(-0.417)\end{array}$ & $\begin{array}{l}0.0083 \\
(0.143)\end{array}$ & $\begin{array}{l}0.0516 \\
(1.482)\end{array}$ & $\begin{array}{c}0.1438 \\
(5.238)\end{array}$ & 9 & 23 \\
\hline $\mathrm{d}_{-2}$ & $\begin{array}{r}0.0223 \\
(0.577)\end{array}$ & $\begin{array}{l}-0.1296 \\
(-1.371)\end{array}$ & $\begin{array}{l}-0.0060 \\
(-0.211)\end{array}$ & $\begin{array}{r}0.0195 \\
(0.594)\end{array}$ & $\begin{array}{l}0.0499 \\
(1.140)\end{array}$ & $\begin{array}{l}0.1398 \\
(4.058)\end{array}$ & 7 & 18 \\
\hline $\mathrm{d}_{-1}$ & $\begin{array}{r}0.0449 \\
(1.173)\end{array}$ & $\begin{array}{l}-0.0910 \\
(-1.743)\end{array}$ & $\begin{array}{l}0.0037 \\
(0.113)\end{array}$ & $\begin{array}{l}0.0271 \\
(0.874)\end{array}$ & $\begin{array}{l}0.0867 \\
(2.057)\end{array}$ & $\begin{array}{l}0.3337 \\
(5.034)\end{array}$ & 14 & 36 \\
\hline $\mathrm{d}_{0}$ & $\begin{array}{r}0.0639 \\
(1.655)\end{array}$ & $\begin{array}{l}-0.0385 \\
(-1.658)\end{array}$ & $\begin{array}{r}0.0344 \\
(0.890)\end{array}$ & $\begin{array}{l}0.0547 \\
(1.574)\end{array}$ & $\begin{array}{l}0.0971 \\
(2.438)\end{array}$ & $\begin{array}{l}0.3959 \\
(5.990)\end{array}$ & 20 & 51 \\
\hline $\mathrm{d}_{1}$ & $\begin{array}{r}0.0134 \\
(0.553)\end{array}$ & $\begin{array}{l}-0.0968 \\
(-1.127)\end{array}$ & $\begin{array}{l}-0.0145 \\
(-0.386)\end{array}$ & $\begin{array}{r}0.0200 \\
(0.660)\end{array}$ & $\begin{array}{l}0.0374 \\
(1.268)\end{array}$ & $\begin{array}{l}0.1042 \\
(3.093)\end{array}$ & 2 & 5 \\
\hline $\mathrm{d}_{2}$ & $\begin{array}{r}-0.0047 \\
(0.019)\end{array}$ & $\begin{array}{l}-0.3025 \\
(-2.729)\end{array}$ & $\begin{array}{l}-0.0193 \\
(-0.616)\end{array}$ & $\begin{array}{l}-0.0020 \\
(-0.096)\end{array}$ & $\begin{array}{l}0.0218 \\
(0.735)\end{array}$ & $\begin{array}{l}0.1651 \\
(2.575)\end{array}$ & 4 & 10 \\
\hline $\mathrm{d}_{3}$ & $\begin{array}{r}-0.0052 \\
(0.127)\end{array}$ & $\begin{array}{l}-0.2740 \\
(-2.906)\end{array}$ & $\begin{array}{l}-0.0182 \\
(-0.575)\end{array}$ & $\begin{array}{l}-0.0028 \\
(-0.062)\end{array}$ & $\begin{array}{l}0.0321 \\
(0.794)\end{array}$ & $\begin{array}{l}0.0810 \\
(2.259)\end{array}$ & 5 & 13 \\
\hline$F_{\text {lag }}$ & 1.1057 & 0.1885 & 0.4581 & 0.6600 & 1.4655 & 4.7377 & 6 & 15 \\
\hline$F_{\text {lead }}$ & 2.3026 & 0.1404 & 0.5364 & 1.6104 & 2.5393 & 23.126 & 19 & 49 \\
\hline
\end{tabular}


Table 5. Lead-lag Relationship Between $A$ Share and $B$ Share Returns: Shanghai and Shenzhen

The table reports results for the following regression:

$$
R_{B, t}=d_{0}+\sum_{k=-3}^{3} d_{k} R_{A, t+k}+\varepsilon_{B, t}
$$

where $R_{B, t}$ is the $B$ share return on day $t$, and $R_{A, t+k}$ is the $A$ share return on day $t+k$. For $k<0, \mathrm{~N}^{*}$ is number of stocks for which $d_{k}$ is significant at the $10 \%$ level. $\mathrm{F}_{\text {lead }}$ is an F-statistic that tests whether $d_{-1}=$ $d_{-2}=d_{-3}=0 . \mathrm{F}_{\text {lag }}$ is an F-statistic that tests whether $d_{1}=d_{2}=d_{3}=0$. There are 23 stocks listed in Shanghai, and 16 in Shenzhen.

\begin{tabular}{|c|c|c|c|c|c|c|c|c|}
\hline Coefficient & mean & Min & $\mathrm{q}_{1}$ & $\begin{array}{c}\text { Median } \\
\text { Quartiles }\end{array}$ & $\mathrm{q}_{3}$ & Max & $\mathrm{N}^{*}$ & $\%$ \\
\hline \multicolumn{9}{|c|}{ Panel A: Shanghai Stock Exchange $(\mathrm{N}=23)$} \\
\hline $\mathrm{d}_{-3}$ & $\begin{array}{l}-0.0026 \\
(-0.062)\end{array}$ & $\begin{array}{l}-0.0616 \\
(-1.853)\end{array}$ & $\begin{array}{l}-0.0223 \\
(-0.819)\end{array}$ & $\begin{array}{l}-0.0037 \\
(-0.136)\end{array}$ & $\begin{array}{l}0.0145 \\
(0.465)\end{array}$ & $\begin{array}{l}0.0796 \\
(2.219)\end{array}$ & 2 & 9 \\
\hline $\mathrm{d}_{-2}$ & $\begin{array}{l}0.0011 \\
(0.151)\end{array}$ & $\begin{array}{l}-0.1296 \\
(-1.371)\end{array}$ & $\begin{array}{l}-0.0120 \\
(-0.448)\end{array}$ & $\begin{array}{l}0.0051 \\
(0.218)\end{array}$ & $\begin{array}{l}0.0249 \\
(0.779)\end{array}$ & $\begin{array}{c}0.0408 \\
(1.188)\end{array}$ & 0 & 0 \\
\hline $\mathrm{d}_{-1}$ & $\begin{array}{l}0.0266 \\
(0.879)\end{array}$ & $\begin{array}{l}-0.0633 \\
(-1.742)\end{array}$ & $\begin{array}{r}0.0037 \\
(0.113)\end{array}$ & $\begin{array}{l}0.0195 \\
(0.845)\end{array}$ & $\begin{array}{l}0.0523 \\
(1.295)\end{array}$ & $\begin{array}{c}0.1175 \\
(3.488)\end{array}$ & 6 & 26 \\
\hline $\mathrm{d}_{0}$ & $\begin{array}{r}0.0546 \\
(1.966)\end{array}$ & $\begin{array}{l}-0.0385 \\
(-1.658)\end{array}$ & $\begin{array}{l}0.0344 \\
(1.163)\end{array}$ & $\begin{array}{l}0.0547 \\
(1.893)\end{array}$ & $\begin{array}{c}0.0988 \\
(3.161)\end{array}$ & $\begin{array}{r}0.1213 \\
(5.990)\end{array}$ & 15 & 65 \\
\hline$d_{1}$ & $\begin{array}{c}0.0078 \\
(0.087)\end{array}$ & $\begin{array}{l}-0.0423 \\
(-1.255)\end{array}$ & $\begin{array}{l}-0.0185 \\
(-0.616)\end{array}$ & $\begin{array}{l}-0.0020 \\
(-0.096)\end{array}$ & $\begin{array}{c}0.0172 \\
(0.771)\end{array}$ & $\begin{array}{c}0.1651 \\
(1.423)\end{array}$ & 0 & 0 \\
\hline $\mathrm{d}_{2}$ & $\begin{array}{l}0.0220 \\
(0.792)\end{array}$ & $\begin{array}{l}-0.0517 \\
(-0.718)\end{array}$ & $\begin{array}{l}-0.0076 \\
(-0.303)\end{array}$ & $\begin{array}{r}0.0238 \\
(0.997)\end{array}$ & $\begin{array}{c}0.0374 \\
(1.328)\end{array}$ & $\begin{array}{c}0.1042 \\
(3.093)\end{array}$ & 4 & 17 \\
\hline$d_{3}$ & $\begin{array}{c}0.0068 \\
(0.241)\end{array}$ & $\begin{array}{l}-0.0258 \\
(-1.067)\end{array}$ & $\begin{array}{l}-0.0118 \\
(-0.306)\end{array}$ & $\begin{array}{c}0.0012 \\
(0.050)\end{array}$ & $\begin{array}{r}0.0307 \\
(0.730)\end{array}$ & $\begin{array}{r}0.0803 \\
(2.259)\end{array}$ & 2 & 9 \\
\hline $\begin{array}{l}\mathrm{F}_{\text {lag }} \\
\mathrm{F}_{\text {lead }}\end{array}$ & $\begin{array}{l}0.9827 \\
1.1780 \\
\end{array}$ & $\begin{array}{l}0.1885 \\
0.2876\end{array}$ & $\begin{array}{l}0.4581 \\
0.4432 \\
\end{array}$ & $\begin{array}{l}0.6241 \\
0.6659\end{array}$ & $\begin{array}{l}1.4655 \\
1.8719 \\
\end{array}$ & $\begin{array}{l}4.4855 \\
4.7458 \\
\end{array}$ & $\begin{array}{l}3 \\
8 \\
\end{array}$ & $\begin{array}{l}13 \\
35 \\
\end{array}$ \\
\hline \multicolumn{9}{|c|}{ Panel B: Shenzhen Stock Exchange $(\mathrm{N}=16)$} \\
\hline $\mathrm{d}_{-3}$ & $\begin{array}{l}0.0543 \\
(1.263)\end{array}$ & $\begin{array}{l}-0.0336 \\
(-0.833)\end{array}$ & $\begin{array}{l}0.0338 \\
(0.454)\end{array}$ & $\begin{array}{l}0.0613 \\
(1.272)\end{array}$ & $\begin{array}{l}0.0816 \\
(1.937)\end{array}$ & $\begin{array}{c}0.1438 \\
(5.238)\end{array}$ & 7 & 44 \\
\hline $\mathrm{d}_{-2}$ & $\begin{array}{r}0.0529 \\
(1.189)\end{array}$ & $\begin{array}{l}-0.0383 \\
(-0.881)\end{array}$ & $\begin{array}{l}0.0113 \\
(0.229)\end{array}$ & $\begin{array}{l}0.0599 \\
(1.181)\end{array}$ & $\begin{array}{l}0.0898 \\
(2.015)\end{array}$ & $\begin{array}{c}0.1398 \\
(4.058)\end{array}$ & 7 & 44 \\
\hline $\mathrm{d}_{-1}$ & $\begin{array}{r}0.07122 \\
(1.597)\end{array}$ & $\begin{array}{l}-0.0910 \\
(-0.342)\end{array}$ & $\begin{array}{l}0.0036 \\
(0.109)\end{array}$ & $\begin{array}{l}0.0761 \\
(1.711)\end{array}$ & $\begin{array}{l}0.1085 \\
(2.372)\end{array}$ & $\begin{array}{r}0.3337 \\
(5.034)\end{array}$ & 8 & 50 \\
\hline $\mathrm{d}_{0}$ & $\begin{array}{c}0.0772 \\
(1.209)\end{array}$ & $\begin{array}{l}-0.0310 \\
(-1.208)\end{array}$ & $\begin{array}{l}0.0284 \\
(0.605)\end{array}$ & $\begin{array}{l}0.0528 \\
(1.197)\end{array}$ & $\begin{array}{r}0.0760 \\
(1.702)\end{array}$ & $\begin{array}{r}0.3959 \\
(3.581)\end{array}$ & 5 & 31 \\
\hline$d_{1}$ & $\begin{array}{l}-0.0228 \\
(-0.077)\end{array}$ & $\begin{array}{l}-0.3025 \\
(-2.729)\end{array}$ & $\begin{array}{c}-0.0394 \\
(-0.699)\end{array}$ & $\begin{array}{l}0.0010 \\
(0.025)\end{array}$ & $\begin{array}{l}0.0279 \\
(0.615)\end{array}$ & $\begin{array}{l}0.0665 \\
(2.575)\end{array}$ & 2 & 12 \\
\hline $\mathrm{d}_{2}$ & $\begin{array}{l}0.0011 \\
(0.210)\end{array}$ & $\begin{array}{l}-0.0968 \\
(-1.127)\end{array}$ & $\begin{array}{l}-0.0366 \\
(-0.643)\end{array}$ & $\begin{array}{l}0.0069 \\
(0.181)\end{array}$ & $\begin{array}{r}0.0402 \\
(1.083)\end{array}$ & $\begin{array}{c}0.1002 \\
(1.523)\end{array}$ & 0 & 0 \\
\hline$d_{3}$ & $\begin{array}{l}-0.0225 \\
(-0.035) \\
\end{array}$ & $\begin{array}{r}-0.2740 \\
(-2.906) \\
\end{array}$ & $\begin{array}{r}-0.0336 \\
(-0.802) \\
\end{array}$ & $\begin{array}{r}-0.010 \\
(-0.229) \\
\end{array}$ & $\begin{array}{r}0.0350 \\
(1.048) \\
\end{array}$ & $\begin{array}{r}0.0810 \\
(1.757) \\
\end{array}$ & 3 & 19 \\
\hline $\mathrm{F}_{\text {lag }}$ & 1.2825 & 0.2303 & 0.4758 & 0.6637 & 1.5342 & 4.7377 & 3 & 19 \\
\hline $\mathrm{F}_{\text {lead }}$ & 3.9192 & 0.1404 & 1.2473 & 2.6482 & 4.1798 & 23.1261 & 11 & 69 \\
\hline
\end{tabular}




\section{Table 6. English Media Coverage and the B Share Price Discount}

The table reports the results of the rank correlations between the number of citations from the Wall Street Journal index and the $B$ share price discounts from 1994 to 1996.

\begin{tabular}{llll}
\hline & $\mathrm{N}$ & Rank Correlation & P-value \\
& & & \\
Shanghai $B$ shares & 23 & -0.3937 & 0.0699 \\
Shenzhen $B$ shares & 16 & -0.4813 & 0.0693 \\
\hline
\end{tabular}

Table 7. cross-sectional Regression of $B$ Share Discounts

The table reports results from the following regression:

$$
\text { DIS }_{i}=a_{0}+a_{1} D_{i}+a_{2} S B A_{i}+a_{3} V_{A R B}+a_{4} S B F_{i}+a_{5} I N F O_{i}+a_{6} S_{Z} E_{i}+a_{7} R A B_{i}+\varepsilon_{i}
$$

For stock $i, D I S_{i}=\left(P_{a i}-P_{b i}\right) / P_{a i}, S B A_{i}=\operatorname{Cov}\left(u_{a i}, u_{b i}\right) / \operatorname{Var}\left(P_{a i}\right), \operatorname{VARB} B_{i}=\operatorname{Var}\left(u_{b i}\right), S B F_{i}=\operatorname{Cov}\left(u_{c}, u_{b i}\right) / \operatorname{Var}\left(u_{c}\right)$. where $P_{a i}$ and $P_{b i}$ are the $A$ and $B$ share prices and $u_{a i}$ and $u_{b i}$ are the $A$ and $B$ share returns for stock $i$, respectively. $u_{c}$ is the return on the $\mathrm{S} \& \mathrm{P} 500$ index. $I N F O_{i}$ is the number of times stock $i$ is cited in the Wall Street Journal index, $S I Z E_{i}$ is the market capitalization, and $R A B_{i}$ is the ratio of $A$ shares to $B$ shares outstanding. The dummy variable $D=1$ for stocks traded on Shanghai stock exchange, and zero otherwise. The t-statistics, in parentheses, are corrected for heteroskedasticity following White (1980). The sample period is January 1994 to December 1996.

\begin{tabular}{|c|c|c|c|c|c|c|c|c|c|}
\hline \multicolumn{10}{|c|}{ Coefficient estimates } \\
\hline Model & $\mathrm{a}_{0}$ & $\mathrm{a}_{1}$ & $\mathrm{a}_{2}$ & $\mathrm{a}_{3}$ & $\mathrm{a}_{4}$ & $\mathrm{a}_{5}$ & $\mathrm{a}_{6}$ & $\mathrm{a}_{7}$ & $\begin{array}{l}\text { Adj. } \\
R^{2}\end{array}$ \\
\hline 1 & $\begin{array}{c}0.437 \\
(8.371 * *)\end{array}$ & $\begin{array}{c}0.281 \\
(5.921 * *)\end{array}$ & $\begin{array}{c}-0.285 \\
(-1.046)\end{array}$ & $\begin{array}{c}0.057 \\
(1.989 *)\end{array}$ & $\begin{array}{c}-0.067 \\
(-0.907)\end{array}$ & & & & 0.39 \\
\hline 2 & $\begin{array}{c}0.446 \\
(9.548 * *)\end{array}$ & $\begin{array}{c}0.333 \\
(7.179 * *)\end{array}$ & $\begin{array}{c}-0.378 \\
(-1.595)\end{array}$ & $\begin{array}{c}0.102 \\
(3.734 * *)\end{array}$ & $\begin{array}{c}-0.070 \\
(-1.153)\end{array}$ & $\begin{array}{c}-0.0004 \\
(-3.597 * *)\end{array}$ & & & 0.50 \\
\hline 3 & $\begin{array}{c}0.540 \\
(9.184 * *)\end{array}$ & $\begin{array}{c}0.219 \\
\left(3.708^{* *}\right)\end{array}$ & $\begin{array}{c}-0.204 \\
(-1.098)\end{array}$ & $\begin{array}{c}0.082 \\
(3.607 * *)\end{array}$ & $\begin{array}{c}-0.086 \\
\left(-1.725^{*}\right)\end{array}$ & $\begin{array}{c}-0.0002 \\
\left(-1.850^{*}\right)\end{array}$ & $\begin{array}{c}-0.00008 \\
\left(-3.676^{* *}\right)\end{array}$ & & 0.58 \\
\hline 4 & $\begin{array}{c}0.662 \\
(11.947 * *)\end{array}$ & $\begin{array}{c}0.143 \\
\left(2.985^{* *}\right)\end{array}$ & $\begin{array}{c}-0.155 \\
(-1.345)\end{array}$ & $\begin{array}{c}0.095 \\
(4.792 * *)\end{array}$ & $\begin{array}{c}-0.028 \\
(-0.599)\end{array}$ & $\begin{array}{c}-0.0003 \\
\left(-3.216^{* *}\right)\end{array}$ & $\begin{array}{c}-0.00008 \\
\left(-4.251^{* *}\right)\end{array}$ & $\begin{array}{c}-0.122 \\
\left(-3.705^{* *}\right)\end{array}$ & 0.67 \\
\hline
\end{tabular}

* - Significance at the $5 \%$ level

** - Significance at the $1 \%$ level 


\section{Figure 1. Daily Average Discounts for Class $B$ Shares}

The average discounts for $B$ shares are calculated as the daily mean of $D_{i t}=\left(P_{a i t}-P_{b i t}\right) / P_{a i t}$, where, for stock $i$ on day $t, P_{a i t}$ and $P_{b i t}$ are the $A$ and $B$ share prices, respectively. The sample consists of 39 stocks with both $A$ and $B$ shares, of which 23 are listed in Shanghai, and 16 in the Shenzhen stock exchange. The sample period is January 1994 through December 1996.

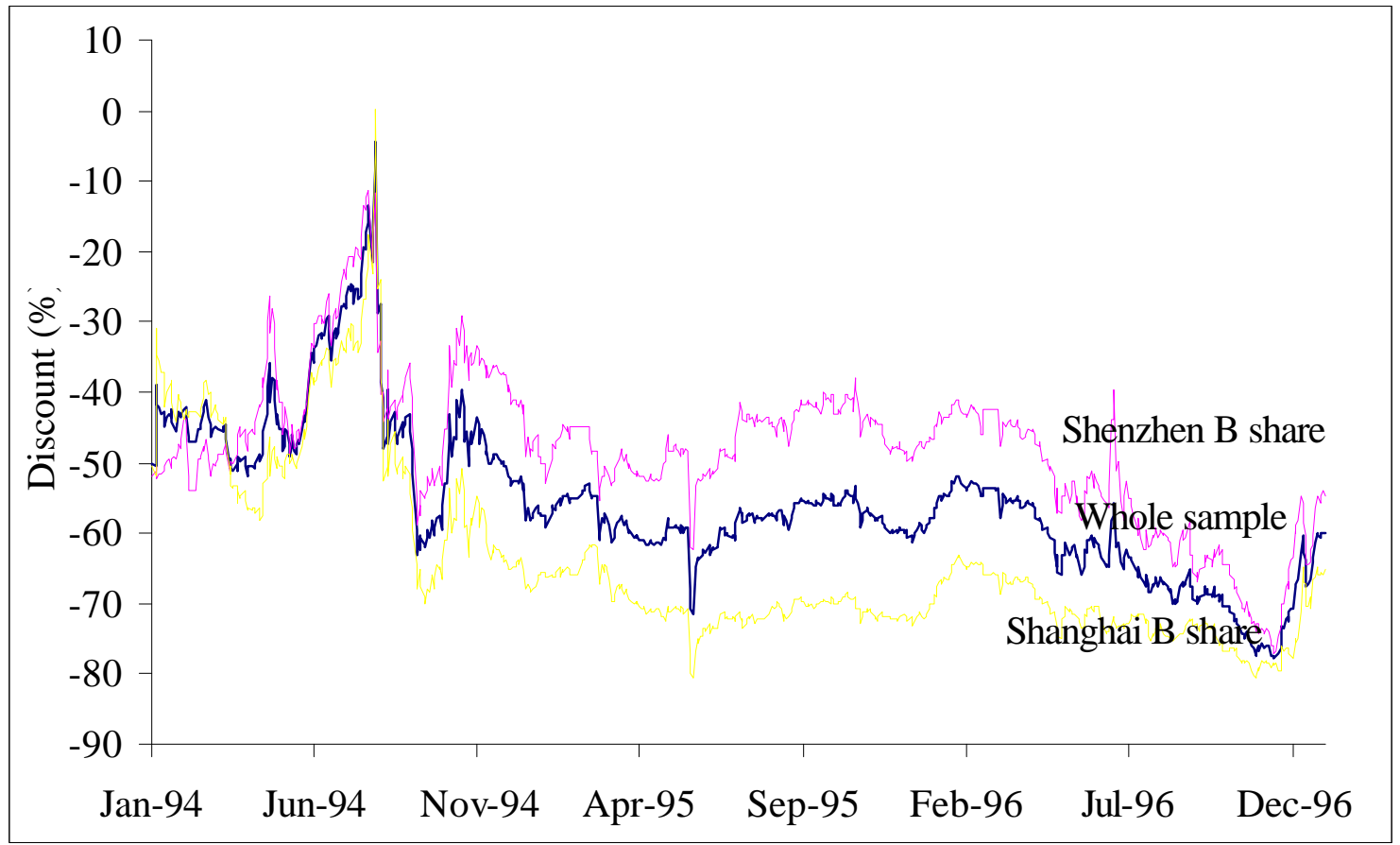

